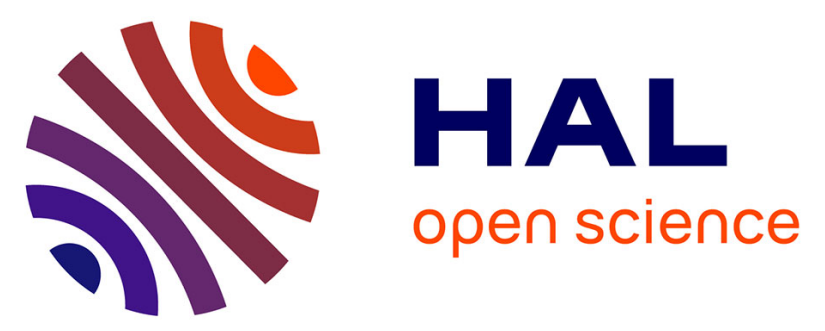

\title{
Aryl hydrocarbon receptor-dependent up-regulation of the heterodimeric amino acid transporter LAT1 (SLC7A5)/CD98hc (SLC3A2) by diesel exhaust particle extract in human bronchial epithelial cells
}

\author{
Marc Le Vee, Elodie Jouan, Valérie Lecureur, Olivier Fardel
}

\section{To cite this version:}

Marc Le Vee, Elodie Jouan, Valérie Lecureur, Olivier Fardel. Aryl hydrocarbon receptor-dependent upregulation of the heterodimeric amino acid transporter LAT1 (SLC7A5)/CD98hc (SLC3A2) by diesel exhaust particle extract in human bronchial epithelial cells. Toxicology and Applied Pharmacology, 2016, 290, pp.74-85. 10.1016/j.taap.2015.11.014 . hal-01237095

HAL Id: hal-01237095

https://hal-univ-rennes1.archives-ouvertes.fr/hal-01237095

Submitted on 22 Mar 2016

HAL is a multi-disciplinary open access archive for the deposit and dissemination of scientific research documents, whether they are published or not. The documents may come from teaching and research institutions in France or abroad, or from public or private research centers.
L'archive ouverte pluridisciplinaire HAL, est destinée au dépôt et à la diffusion de documents scientifiques de niveau recherche, publiés ou non, émanant des établissements d'enseignement et de recherche français ou étrangers, des laboratoires publics ou privés. 
Aryl hydrocarbon receptor-dependent up-regulation of the heterodimeric amino acid transporter LAT1 (SLC7A5)/CD98hc (SLC3A2) by diesel exhaust particle extract in human bronchial epithelial cells

Marc LE VEE ${ }^{\mathrm{a}}$, Elodie JOUAN ${ }^{\mathrm{a}}$, Valérie LECUREUR ${ }^{\mathrm{a}}$ and Olivier FARDEL ${ }^{\mathrm{a}, \mathrm{b}, *}$

${ }^{a}$ Institut de Recherches en Santé, Environnement et Travail (IRSET), UMR INSERM U1085, Faculté de Pharmacie, 2 Avenue du Pr Léon Bernard, 35043 Rennes, France

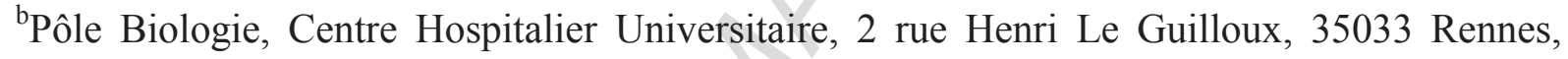
France

* Corresponding author. Fax : +33223234794.

E-mail address: olivier.fardel@univ-rennes1.fr (O. Fardel).

Abbreviations: AhR, aryl hydrocarbon receptor; $\mathrm{BCH}, 2$-aminobicyclo-(2,2,1)-heptane-2carboxylic acid; CYP, cytochrome P-450; DEP, diesel exhaust particle; DEPe, diesel exhaust particle extract; DMSO, dimethyl sulfoxide; EGR1, early growth response 1; ERK, extracellular regulated kinase; FAK, focal adhesion kinase; LAT, L-type amino acid transporter; MMP, metalloproteinase; mTORC1, mammalian target of rapamycin complex 1; p70S6K, p70S6 kinase; PAH, polycyclic aromatic hydrocarbon; PI3K, phosphatidylinositol-3 kinase. 


\section{ABSTRACT}

The heterodimeric L-type amino acid transporter (LAT) 1/ CD98hc is overexpressed in lung cancers with a poor prognosis factor. Factors that contribute to LAT1/CD98hc overexpression in lung cells remain however to be determined, but the implication of atmospheric pollution can be suspected. The present study was therefore designed to analyze the effects of diesel exhaust particle (DEP) extract (DEPe) on LAT1/CD98hc expression in bronchial epithelial BEAS-2B cells. Exposure to DEPe up-regulated LAT1 and CD98hc mRNA levels in a concentration-dependent manner, with DEPe $\mathrm{EC}_{50}$ values (around $0.2 \mu \mathrm{g} / \mathrm{mL}$ ) relevant to environmental situations. DEPe concomitantly induced LAT1/CD98hc protein expression and LAT1-mediated leucine accumulation in BEAS-2B cells. Inhibition of the aryl hydrocarbon receptor (AhR) pathway through the use of a chemical AhR antagonist or the siRNAmediated silencing of AhR expression was next found to prevent DEPe-mediated induction of LAT1/CD98hc, indicating that this regulation depends on AhR, known to be activated by major chemical DEP components like polycyclic aromatic hydrocarbons. DEPe exposure was finally shown to induce mRNA expression and activity of matrix metalloproteinase (MMP)-2 in BEAS-2B cells, in a CD98hc/focal adhesion kinase (FAK)/extracellular regulated kinase (ERK) manner, thus suggesting that DEPe-mediated induction of CD98hc triggers activation of the integrin/FAK/ERK signaling pathway known to be involved in MMP-2 regulation. Taken together, these data demonstrate that exposure to DEPe induces functional overexpression of the amino acid transporter LAT1/CD98h in lung cells. Such a regulation may participate to pulmonary carcinogenic effects of DEPs, owing to the well-documented contribution of LAT1 and CD98hc to cancer development. 


\section{INTRODUCTION}

L-type amino acid transporter (LAT) $1 / \mathrm{CD} 98 \mathrm{hc}$ is a heterodimeric plasma membrane protein consisting of a light chain (LAT1, encoded by the SLC7A5 gene) linked to a heavy chain (CD98hc, also known as 4F2hc, and encoded by the SLC3A2 gene) by an extracellular disulfide bridge (Fotiadis et al., 2013). LAT1 is responsible for L-type sodium-independent uptake of large neutral amino acids such as leucine, isoleucine, methionine or tyrosine across cell membrane (Kanai et al., 1998). Molecular basis of this transport corresponds to an obligatory amino acid exchange with 1:1 stoichiometry (Verrey, 2003); the efflux substrate is in parallel handled by a sodium-dependent unidirectional influx system $\mathrm{A}$ or $\mathrm{N}$ amino acid transporter, that appears therefore to be the primary source of the driving force for LAT1mediated transport. In addition to neutral amino acids, thyroid hormones as well as a few drugs like L-DOPA, alpha-methyldopa, melphalan, and gabapentin are transported by LAT1 (del Amo et al., 2008; Kinne et al., 2011). With respect to the heavy chain CD98hc, it serves as a chaperone for LAT1, allowing to localize and stabilize it at the plasma membrane of cells, without transport function (Palacin and Kanai, 2004). CD98hc also plays this role towards other amino acid transporters to which it is covalently linked such as LAT2/SLC7A8 and the L-type sodium-dependent amino acid transporters $\mathrm{y}^{+}$LAT1/SLC7A7 and $\mathrm{y}^{+}$LAT2/SLC7A6 (Fotiadis et al., 2013).

Amino acids transported by LAT1 serve not only for protein synthesis, but also as signaling molecules (Taylor, 2014). The essential amino acid leucine is thus a master regulator of mammalian target of rapamycin complex 1 (mTORC1) (Nicklin et al., 2009), a signaling pathway involved in promotion of cellular growth through phosphorylation of substrates that potentiate anabolic processes such as mRNA translation and lipid synthesis, or limit catabolic processes such as autophagy (Laplante and Sabatini, 2012). By this way, LAT1 is thought to favor cancer cell proliferation and metastasis (Fuchs and Bode, 2005; Wang and 
Holst, 2015). CD98hc also independently promotes cancer development, through its direct binding to $\beta$-integrins (mainly $\beta 1$ but also $\beta 3$ ), which is presumed to modulate tumorigenic integrin-dependent events such as survival, proliferation, migration and transformation (Feral et al., 2005). As an example, CD98hc has been shown to control activity of focal adhesion kinase (FAK), an integrin-related signaling way, which in turn may result in modulation of the matrix metalloproteinase (MMP)-2 (Santiago-Gomez et al., 2013), strongly implicated in cancer progression (Bauvois, 2012).

Both LAT1 and CD98hc have been shown to be overexpressed in many cancers (Kaira et al., 2008). They are notably detected in non-small cell lung cancers, for which they are considered as poor prognosis parameters (Imai et al., 2009; Kaira et al., 2010; Fei et al., 2014). Regulatory factors that may be involved in the induction of their expression in lung cells remain however to be characterized. A role for atmospheric pollutants may be suspected, notably for diesel exhaust particles (DEPs), which are now recognized as carcinogenic for the lung (Vermeulen et al., 2014). Indeed, DEPs, originating from diesel engines and to which humans are widely exposed in industrialized and/or urban areas (Gouge et al., 2010), are composed of a center core of elemental carbon to which various chemicals, especially polycyclic aromatic hydrocarbons (PAHs), are adsorbed (Wichmann, 2007) and such PAHs are potent activators of the aryl hydrocarbon receptor (AhR) signaling pathway (Puga et al., 2009), involved in LAT1 mRNA up-regulation in hepatocytes (Sarkar et al., 1999; Le Vee et al., 2010). The present study was therefore designed to determine whether exposure to DEP extract (DEPe) can regulate LAT1/CD98hc in human bronchial epithelial BEAS-2B cells. Our results indicate that DEPe induces expression of both LAT1 and CD98he in an AhRdependent manner in lung BEAS-2B cells. DEPe is also demonstrated to concomitantly increase uptake of leucine and to up-regulate MMP-2 in a CD98hc-dependent manner, thus 
bringing evidence that DEPe-mediated up-regulation of LAT1/CD98hc has functional consequences in lung cells.

\section{MATERIALS AND METHODS}

\section{Chemicals and reagents}

DEPe used in the study was the Standard Reference Material 1975 (SRM 1975), purchased by the National Institute of Standards and Technology (Gaithersburg, MD, USA). It corresponds to a dichloromethane extract of filter-collected combustion particulate matter from operating forklifts with diesel engines. Some of its chemical components have been previously characterized; SRM 1975 notably contains PAHs such as phenanthrene, fluoranthene, chrysene, triphenylene, benzo[b]fluoranthene and benzo[ghi]perylene and nitroPAHs such as 1-nitropyrene (Hughes et al., 1997). Dichloromethane was evaporated under nitrogen and the final residue was dissolved in dimethyl sulfoxide (DMSO) for cell exposure. Benzo(a)pyrene, benzo(e)pyrene, benzanthracene, 1-nitropyrene, chrysene, CH-223191, actinomycin D, cycloheximide, rapamycin, roscovitine, PF-573228, wortmannin, U0126 and 2-aminobicyclo-(2,2,1)-heptane-2-carboxylic acid $(\mathrm{BCH})$ were purchased from SigmaAldrich (St Louis, MO), whereas 2,3,7,8-tetrachlorodibenzo-p-dioxin (TCDD) was obtained from Cambridge Isotope Laboratories (Cambridge, MA). Hoechst 33342, propidium iodide and TRI Reagent were from Life Technologies (Paisley, United Kingdom). L-[4,5- $\left.{ }^{3} \mathrm{H}\right]$ leucine (sp. act. $37 \mathrm{MBq} / \mathrm{mL}$ ) was provided by Perkin-Elmer (Courtaboeuf, France). Other reagents were commercial products of the highest purity available.

\section{Cell culture and treatments}

The human lung epithelial cell line BEAS-2B was routinely cultured in F12K medium with $2 \mathrm{mM}$ L-glutamine (Gibco, Cergy-Pontoise, France), supplemented with $1 \mathrm{mM}$ Hepes, $10 \%$ (vol/vol) fetal calf serum (Thermo Fisher Scientific, Illkirch, France), $100 \mathrm{IU} / \mathrm{mL}$ 
penicillin and $100 \mathrm{mg} / \mathrm{mL}$ streptomycin. Cells were usually seeded at $11 \times 10^{3}$ cells $/ \mathrm{cm}^{2}$ and treated by DEPe at confluence stage. Chemicals were initially dissolved in DMSO and stored frozen as stock solutions until use. Final concentration of solvent in culture media did not exceed $0.2 \%(\mathrm{vol} / \mathrm{vol})$; control cultures received the same dose of DMSO as for their treated counterparts. When chemical inhibitors were used, they were added $30 \mathrm{~min}$ before DEPe treatment.

\section{Cytotoxicity assays}

Cellular apoptosis or necrosis were investigated through cell staining with $10 \mu \mathrm{g} / \mathrm{mL}$ Hoechst 33342 and $1 \mu \mathrm{g} / \mathrm{mL}$ propidium iodide for $15 \mathrm{~min}$ at $37^{\circ} \mathrm{C}$, as previously described (Le Vee et al., 2014). Apoptotic cells, i.e., cells with condensed blue chromatin or fragmented blue nuclei, and necrotic cells, i.e., cells with red nuclei, were next counted in comparison with total cell population using fluorescence microscopy.

RNA isolation and reverse transcription-quantitative polymerase chain reaction (RT-qPCR) analysis

Total RNAs were extracted using the TRI Reagent method, and then reverse transcribed into cDNAs using the RT kit from Applied Biosystems (Foster City, CA). qPCR assays were next performed using the fluorescent dye SYBR Green methodology and an ABI Prism 7300 detector (Applied Biosystems), as previously described (Le Vee et al., 2009). The gene specific primers used were: CD98hc sense, CCAGGTTCGGGACATAGAGA, CD98hc anti-sense, GAGCCTTGCCTGAGACAAAC,

MMP-2

sense ATGGAGGCGCTAATGGCCCG, MMP-2 anti-sense GTGTTCAGGTATTGCACTGCCAACT, LAT2 sense ACCGAAACAACACCGAAAAG, LAT2 anti-sense GATTCCAGAGCCGATGATGT, LAT3/SLC43A1 sense 
GGACGTGGAAGCTCTGTCTC, LAT3 anti-sense ATGGCAGAAGAGGCGTAAGA, LAT4/SLC43A2 sense GACTGGAGGCTGAAGGAGTG, LAT4 anti-sense ACGATTGTGTGCAGGATGAA, ${ }^{+}$LAT1 sense GCCCTCTACTCTGCCCTCTT, ${ }^{+}$LAT1 anti-sense GTCACAGCCACAGCATCACT, $\mathrm{y}^{+}$LAT2 sense CTCTCCATTGGCATCTCCAT and $\mathrm{y}^{+}$LAT2 anti-sense GAGGCCACCAAAACAGGATA. Primers used for cytochrome P450 (CYP) 1A1, CYP1B1, LAT1 and 18S detection were exactly as previously reported (Le Vee et al., 2010). The specificity of each gene amplification was verified at the end of qPCR reactions through analysis of dissociation curves of the PCR products. Amplification curves were next analyzed with ABI Prism 7000 SDS software using the comparative cycle threshold method. Relative quantification of the steady-state target mRNA levels was calculated after normalization of the total amount of cDNA tested to the 18S RNA endogenous reference using the $2^{(-\Delta \mathrm{Ct})}$ method. Data were routinely expressed as fold-induction factor comparatively to mRNA levels found in untreated cells or, alternatively, in arbitrary units relatively to $18 \mathrm{~S}$ RNA as previously reported (Le Vee et al., 2015a).

\section{RNA interference experiments}

Cells were initially seeded at $2.5 \times 10^{3}$ cells $/ \mathrm{cm}^{2}$ in 12 -well plates. After a 4 daysculture period, cells were washed with phosphate-buffered saline and media was then replaced with opti-MEM (Gibco) containing $8 \mu \mathrm{L} / \mathrm{mL}$ of lipofectamine 2000 (Life Technologies) and 100 pmol of small-interfering RNA (siRNA). Two duplex of siRNAs targeting AhR (si AhR), early growth response 1 (EGR1) (si EGR1) or CD98hc (si CD98hc) mRNAs and one duplex used as a negative non-targeting control (si NT) were purchased from Sigma-Aldrich. After 6 $\mathrm{h}$, this medium was changed by usual medium. Treatment by DEPe was performed after an additional $18 \mathrm{~h}$ culture-period. BEAS-2B cells transfected by siRNAs failed to exhibit 
obvious morphological features of toxicity, as demonstrated by light microscopic examination of the cultures (data not shown).

\section{Western-blot analysis}

Protein extracts were prepared as previously described (van Grevenynghe et al., 2004; Macoch et al., 2015). Protein lysates were then separated on polyacrylamide gel and electrophoretically transferred onto Protan ${ }^{\circledR}$ nitrocellulose membranes (Whatman GmbH, Dassel, Germany). After blocking with Tris-buffered saline containing $4 \%$ (vol/vol) bovine serum albumin and $0.1 \%(\mathrm{vol} / \mathrm{vol})$ Tween 20 for $30 \mathrm{~min}$ at room temperature, membranes were incubated overnight at $4^{\circ} \mathrm{C}$ with primary antibodies against LAT1, CD98hc, EGR1, phospho-extracellular regulated kinase (ERK), phospho-FAK (Tyr 397), phospho-FAK (Tyr 925), phospho-p70S6 kinase (p70S6K), total-p70S6K, phospho-S6, total-S6 (Cell Signaling Technology, Danvers, MA), AhR (Abcam, Cambridge, United Kingdom) or HSC70 (Santa Cruz Biotechnology, CA). After washing, membranes were next re-incubated with appropriate horseradish peroxidase-conjugated secondary antibodies (Dako, Glostrup, Denmark). Immunolabeled proteins were finally visualized by chemiluminescence. Gel loading and transfer were checked up by staining membranes with Ponceau red. Densitometry with ImageJ $1.40 \mathrm{~g}$ software (National Institutes of Health, Bethesda, MD) was used for quantifying intensities of stained bands.

\section{LAT1-mediated transport assay}

LAT1 activity was measured by determining intracellular accumulation of the reference LAT1 substrate leucine in the presence or absence of $1 \mathrm{mM} \mathrm{BCH}$, a welldocumented inhibitor for system L amino acid transporters (Imai et al., 2010). Briefly, cells were incubated at $37^{\circ} \mathrm{C}$ with $0.69 \mathrm{nM} \mathrm{L}-\left[4,5-{ }^{3} \mathrm{H}\right]$ leucine for $5 \mathrm{~min}$ in a well-defined sodium- 
free transport medium consisting of $5.3 \mathrm{mM} \mathrm{KCl}, 1.1 \mathrm{mM} \mathrm{KH}_{2} \mathrm{PO}_{4}, 0.8 \mathrm{mM} \mathrm{MgSO}_{4}, 1.8 \mathrm{mM}$ $\mathrm{CaCl}_{2}, 11 \mathrm{mM}$ D-glucose, $10 \mathrm{mM}$ HEPES and $136 \mathrm{mM} \mathrm{N}$-methyl glucamine and adjusted to $\mathrm{pH} 7.4$, in the absence or presence of $1 \mathrm{mM} \mathrm{BCH}$. After washing in phosphate-buffered saline, cells were lysed and intracellular accumulation of leucine was next determined through scintillation counting.

Zymographic analysis of MMPs

Because MMPs can degrade gelatin, zymographic techniques were used to detect MMP-2 activity in the supernatant of BEAS-2B treated or not by DEPe as previously reported (Manoury et al., 2005). In nonreducing conditions and in the presence of sodium dodecyl sulfate, aliquots of cell culture supernatant underwent electrophoresis onto a $4 \%$ acrylamide stacking gel/ $10 \%$ acrylamide separating gel containing $1 \mathrm{mg} / \mathrm{mL}$ gelatin. After electrophoresis, gels were washed twice with $2.5 \%$ (vol/vol) Triton X-100, rinsed with water, and incubated overnight at $37^{\circ} \mathrm{C}$ in $50 \mathrm{mM}$ Tris, $5 \mathrm{mM} \mathrm{CaCl}_{2}, 2 \mu \mathrm{M} \mathrm{ZnCl}_{2}$, adjusted to $\mathrm{pH} 8$. The gels were next stained with Coomassie Brilliant Blue in a solution of $25 \%$ (vol/vol) ethanol-10\% (vol/ $\mathrm{vol})$ acetic acid in water and rinsed in an identical solution. Gelatinase A activity due to MMP-2 finally appeared as clear $72 \mathrm{kDa}$-bands against blue background (Toth et al., 2012). Recombinant protein molecular weight markers (10-170 kDa) were used in parallel to estimate the molecular weights of the gelatinolytic bands.

\section{Statistical analysis}

Quantitative data were usually expressed as means \pm S.E.M of values from at least three independent experiments. Data were statistically analyzed using analysis of variance followed by the Tukey's post-hoc test or using Student's $t$ test. The criterion of significance was $p<0.05$. Half maximal effective concentration $\left(\mathrm{EC}_{50}\right)$ values were determined using 
GraphPad Prism software (GraphPad Software, La Jolla, CA), through nonlinear regression based on the four parameter logistic function.

\section{RESULTS}

Induction of LAT1/CD98hc expression by DEPe

Beas-2B cells were first exposed to $5 \mu \mathrm{g} / \mathrm{mL}$ DEPe, which corresponds to a 1.31 $\mu \mathrm{g} / \mathrm{cm}^{2}$ equivalent DEP dose according to previous conversions of in vitro DEPe/DEP concentrations to DEP dose/unit surface area (Li et al., 2003) and is in the range of DEPe concentrations usually retained for treating cultured cells (Koike et al., 2002; Schwarze et al., 2013; Jaguin et al., 2015). Treatment of Beas-2B cells by $5 \mu \mathrm{g} / \mathrm{mL}$ DEPe treatment for $48 \mathrm{~h}$ failed to trigger toxicity as demonstrated by light phase-contrast microscopic examination of cell cultures (data not shown) and evaluation of cell apoptosis or necrosis (Fig. S1). Both LAT1 and CD98hc mRNA levels were found to be significantly up-regulated by $5 \mu \mathrm{g} / \mathrm{mL}$ DEPe from $8 \mathrm{~h}$ exposure (Fig. 1A). Longer treatment (up to $48 \mathrm{~h}$ ) did not more enhance SLC3A2 mRNA expression, that was maximally induced by approximately a 3-fold factor in response to DEPe; by contrast, LAT1 mRNA induction factor raised with time exposure, to reach a 5.4-fold factor in response to a $48 \mathrm{~h}$ exposure to DEPe (Fig. 1A). We next demonstrated that the inducing effect of DEPe towards LAT1 and CD98hc mRNA expression was concentration-dependent (Fig. 1B), with $\mathrm{DEPe}^{\mathrm{EC}_{50}}$ values of $0.25 \mu \mathrm{g} / \mathrm{mL}$ and 0.17 $\mu \mathrm{g} / \mathrm{mL}$ for LAT1 and CD98hc, respectively.

In contrast to LAT1, other amino acids transporters covalently linked to CD98he such as LAT2, $\mathrm{y}^{+}$LAT1 and $\mathrm{y}^{+}$LAT2 were not induced by a 48-h exposure to DEPe (Fig. 1C). Similarly, mRNA levels of the membrane facilitator system L amino acid transporters LAT3 and LAT4 were not up-regulated by DEPe (Fig. 1C). 
Western-blotting next indicated that DEPe also induced LAT1 and CD98hc expression at the protein level in BEAS-2B cells (Fig. 2A). These inductions were time-dependent and were maximal after a $48 \mathrm{~h}$ exposure to DEPe, as demonstrated by densitometric analysis of the blots (Fig. 2B).

AhR and EGR1 involvement in DEPe-mediated induction of LAT1/CD98hc

To characterize the molecular mechanisms involved in DEPe-triggered induction of LAT1/CD98hc, we first analyzed the effects of the transcription inhibitor actinomycin D and of the protein synthesis inhibitor cycloheximide. As shown in Fig. 3, actinomycin D prevented both LAT1 and CD98hc up-regulation in response to DEPe, indicating thus that active transcription was required for inducing effects of DEPe towards LAT1/CD98he mRNA expression in BEAS-2B cells. By contrast, cycloheximide failed to inhibit LAT1 and CD98hc mRNA induction by DEPe (Fig. 3), thus showing that DEPe-mediated up-regulation of LAT1/CD98he did not need de novo protein synthesis. Cycloheximide treatment was in fact able to induce by itself CD98hc mRNA levels (Fig. 3), suggesting that an unidentified shortlived protein likely acts as an endogenous repressor of CD98hc expression.

Putative AhR involvement in DEPe-mediated up-regulation of LAT1/CD98hc was next studied. The AhR reference target genes CYP1A1 and CYP1B1 (Kawajiri and FujiiKuriyama, 2007) were found to be markedly induced by DEPe, as soon as an $8 \mathrm{~h}$ exposure to the extract (Fig. S2A), thus providing evidence that the AhR signaling way was activated by DEPe in BEAS-2B cells. DEPe effects towards CYP1A1 and CYP1B1 mRNA levels were concentration-dependent, with $\mathrm{DEPe} \mathrm{EC}_{50}$ values of $0.91 \mu \mathrm{g} / \mathrm{mL}$ and $1.15 \mu \mathrm{g} / \mathrm{mL}$ for CYP1A1 and CYP1B1, respectively (Fig. S2B). The functionality of the AhR signaling cascade in BEAS-2B cells was further confirmed by the fact that several known agonists of AhR, such as TCDD and the PAHs benzo(a)pyrene, benzanthacene and chrysene (Machala et 
al., 2001; Sorg, 2014), induced CYP1A1 mRNA expression in BEAS-2B cells, in a manner similar to DEPe, except for chrysene for which the inducing effect was rather weaker (Fig. 4). By contrast, benzo(e)pyrene and 1-nitropyrene, that are considered as poor activators of AhR (van Grevenynghe et al., 2003; Ovrevik et al., 2010), failed to induce CYP1A1 expression. Interestingly, TCDD, benzo(a)pyrene, benzanthracene and chrysene, unlike benzo(e)pyrene and 1-nitropyrene, induced mRNA expression of LAT1 and CD98hc (Fig. 4). To more directly prove the involvement of AhR in DEPe-mediated regulation of LAT1/CD98hc, the effects of the AhR antagonist CH-223191 (Kim et al., 2006) was next studied. This chemical inhibited CYP1A1 induction by DEPe; it also significantly decreased LAT1 and CD98hc mRNA up-regulation due to DEPe (Fig. 5A). Similarly, transfection of siRNAs against AhR, that resulted in a marked reduction of AhR protein expression (Fig. S3A), abolished induction of CYP1A1, LAT1 and CD98hc by DEPe (Fig. 5B).

Various transcription factors can contribute to the AhR signaling pathway, notably through direct physical interaction with AhR (Hankinson, 2005). It is the case for EGR1, that participates to AhR-mediated regulation of thrombospondin-1 in endothelial cells (Dabir et al., 2008). Transfection of siRNAs targeting EGR1 in BEAS-2B cells, that decreased EGR1 protein expression to $22.9 \pm 5.6 \%$ of the level found in control cells transfected with nontargeting SiRNA (Fig. 6A and Fig. S4A), counteracted DEPe-mediated LAT1 and CD98hc induction in BEAS-2B cells, but failed to act on CYP1A1 up-regulation (Fig. 6B). In the same way, roscovitine, that markedly decreased EGR1 expression in BEAS-2B cells to $28.3 \pm 7.3$ $\%$ of the level found in untreated cells (Fig. 6C and Fig. S4B) through possibly its inhibiting effect towards cyclin-dependent kinases (Lee and Kim, 2004), prevented DEPe-triggered upregulation of LAT1 and CD98hc, but not that of CYP1A1 (Fig. 6D). 
Treatment by DEPe significantly increased uptake of the LAT1 substrate leucine in BEAS-2B cells (Fig. 7A). Moreover, this uptake of leucine was similarly inhibited by the LAT1 inhibitor BCH in both untreated and DEPe-treated BEAS-2B cells (Fig. 7A), thus indicating it was most likely related to LAT1 activity.

By contrast, DEPe treatment for $24 \mathrm{~h}$ or $48 \mathrm{~h}$ failed to enhance phosphorylation of the reference mTORC1 target p70S6K (Dunlop and Tee, 2009) and phosphorylation of the downstream substrate of p70S6K, i.e., the ribosomal protein S6 (Fig. 7B). In this context, it is noteworthy that treatment by the mTORC1 inhibitor rapamycin resulted in a marked reduction of p70S6K and S6 phosphorylation in BEAS-2B cells either exposed or not to DEPe (Fig. 7B), thus likely highlighting a constitutional high activation of the mTORC1 signaling pathway in these lung cells, regardless of DEPe treatment.

CD98hc-dependent induction of MMP-2 expression by DEPe in BEAS-2B cells

In order to determine whether CD98hc up-regulation by DEPe may have functional consequences in BEAS-2B cells, we finally analyzed expression of MMP-2, that has been previously shown to be a target for the CD98hc//1-integrin/FAK signaling way (SantiagoGomez et al., 2013). As indicated in Fig. 8A, exposure to DEPe induced MMP-2 expression in a time-dependent manner, MMP-2 mRNA levels being maximally increased by a 5.7-fold factor after a $48 \mathrm{~h}$ exposure. Gelatinase activity due to MMP-2 was concomitantly increased by DEPe, as demonstrated by zymographic analysis (Fig. 8B). MMP-2 mRNA up-regulation by DEPe was next found to be abolished by cycloheximide (Fig. 8C), thus demonstrating that it required de novo protein synthesis. Abolishing DEPe-mediated CD98hc induction through efficiently knocking-down CD98hc expression at mRNA (Fig. 8D) and protein (Fig. S3B) level using siRNA transfection further prevented induction of MMP-2 by DEPe, but not that of CYP1A1 (Fig. 8D). Taken together, these data are consistent with the assertion that de 
novo enhanced synthesis of CD98hc in response to DEPe is specifically required for MMP-2 up-regulation.

The putative contribution of FAK to MMP-2 regulation by DEPe was characterized using the chemical FAK inhibitor PF-573228 (Slack-Davis et al., 2007). As shown in Fig. S5, PF-573228 effectively inhibited FAK phosphorylation on Tyr (397) and on Tyr (925) in BEAS-2B cells exposed or not to DEPe for $24 \mathrm{~h}$; this DEPe treatment, fully efficient for inducing CD98hc protein expression (Fig. 2), otherwise failed to enhance basal phosphorylated FAK levels in BEAS-2B cells (Fig. S5). PF-573228 prevented MMP-2 upregulation by DEPe, without impairing those of CD98he and CYP1A1 (Fig. 9A).

Participation to DEPe-mediated MMP-2 induction of signaling ways such as the mitogen-activated protein kinase ERK and the phosphatidylinositol-3 kinase (PI3K)/Akt, that are presumed to act downstream of FAK (Sawai et al., 2005; Santiago-Gomez et al., 2013), was finally studied. The ERK inhibitor U0126, which effectively blocked ERK phosphorylation in BEAS-2B cells either exposed or not to DEPe (Fig. S5), prevented MMP2 up-regulation by DEPe, without inhibiting those of CD98hc and CYP1A1 (Fig. 9B). Phosphorylated ERK levels did not however vary in a major way in BEAS-2B cells in response to a $24 \mathrm{~h}$ treatment by DEPe (Fig. S5). U0126 by itself was otherwise found to induce mRNA expression of CD98hc and CYP1A1 (Fig. 9B), which likely reflects the fact that U0126 can activate AhR (Andrieux et al., 2004). In contrast to U0126, the PI3K/Akt inhibitor wortmannin did not block DEPe-triggered induction of MMP-2 (data not shown).

\section{DISCUSSION}

The present study indicates that exposure to DEPe increases expression of the heterodimeric amino acid transporter LAT1/CD98hc in lung epithelial cells. Indeed, treatment of lung BEAS-2B cells by DEPe coordinately up-regulated each of the two subunits of the 
transporter, i.e., the catalytic LAT1 and the chaperone CD98hc, at both mRNA and protein levels in BEAS-2B cells. This up-regulation of LAT1/CD98hc was otherwise not a part of a putative general/unspecific alteration of system L amino acid transporter expression by DEPe exposure because LAT3 and LAT4, as well as other CD98hc-linked amino acid transporters such as $\mathrm{y}^{+}$LAT1 and $\mathrm{y}^{+}$LAT2, were not induced by DEPe. Environmental atmospheric pollutants like DEPe can therefore be unambiguously added to the list of factors specifically targeting LAT1, comprising estrogens (Soulez and Parker, 2001), nutrients (Drummond et al., 2010) or hypoxic stimuli (Elorza et al., 2012). Interestingly, in addition to LAT1/CD98hc, the efflux drug transporters P-glycoprotein/ABCB1 and breast cancer resistance protein/ABCG2 are induced in response to DEPs/DEPe (Hartz et al., 2008; Le Vee et al., 2015b). Moreover, PAHs, that represent major chemical components of DEPe, also regulate expression of the drug transporter multidrug resistance protein 4/ABCC4 (Xu et al., 2010). Taken together, these data indicate that membrane transporters constitute targets for DEPs or DEPs-related chemicals. This conclusion is additionally fully supported by the fact that activity of some drug transporters such as multidrug resistance protein $2 / A B C C 2$ and the organic anion transporting polypeptides 1B1/SLCO1B1 and 1B3/SLCO1B3 can be markedly and directly impaired by DEPe (Le Vee et al., 2015b).

The molecular mechanism involved in LAT1/CD98hc induction by DEPe most likely involves AhR. Indeed, several arguments are in favor of this conclusion: (i) DEPe effectively activated the AhR signaling pathway in BEAS-2B cells, as demonstrated by the up-regulation of the AhR reference target genes CYP1A1 and CYP1B1, (ii) the $\mathrm{EC}_{50}$ values for DEPemediated up-regulation of LAT1 and CD98hc mRNA levels are in the range of those for DEPe-related induction of CYP1A1 and CYP1B1, suggesting that these regulations share the same way of signaling, (iii) DEPe-related PAHs that are known to activate the AhR, such as benzo(a)pyrene or benzanthracene, also increased expression of LAT1 and CD98hc, in 
contrast to PAHs not, or only poorly, activating AhR, such as benzo(e)pyrene and 1nitropyrene, (iv) the reference AhR ligand TCDD induced expression of LAT1, in agreement with previous results (Sarkar et al., 1999; Le Vee et al., 2010), and also that of CD98hc and (v) abolition of the AhR signaling cascade using chemical AhR antagonist or silencing of AhR expression prevented DEPe-mediated regulation of LAT1/CD98hc. Because experiments with actinomycin D and cycloheximide have indicated that DEPe-mediated induction of LAT1/CD98hc mRNA required active transcription, but not protein synthesis, a direct transcriptional regulation by AhR of LAT1/SLC7A5 and CD98hc/SLC3A2 genes through its cognate DNA motif, dioxin-response element (DRE), may be hypothesized, as well-documented for AhR-dependent regulation of reference AhR target genes like CYP1A1 and CYP1B1 genes (Kawajiri and Fujii-Kuriyama, 2007). The fact that several core DRE (GCGTG) sequences were found in the promoters of LAT1/SLC7A5 and CD98hc/SLC3A2 genes (data not shown) is consistent with this hypothesis. Further studies, including promoter deletion analysis, would be however required to determine whether these DRE sequences are functional. Importantly, the requirement of AhR activation for DEPe-mediated induction of LAT1/CD98hc indicates that DEPe-contained chemicals implicated in this regulation are necessary AhR agonists. In this context, PAHs, that correspond to main chemicals adsorbed on DEPs (Wichmann, 2007), can be highly suspected. It is however noteworthy that DEPs contain various different PAHs and the induction of LAT1/CD98hc by DEPe may therefore reflect the exposure to a complex mixture of PAHs rather than that to a single PAH.

Various cofactors of AhR have been described, including EGR1 (Dabir et al., 2008). Repression of this transcription factor through siRNA transfection or roscovitine treatment was found to prevent DEPe-mediated induction of LAT1/CD98hc, thus suggesting that EGR1 acts as a required coactivator of $\mathrm{AhR}$ for the regulation of the amino acid transporter subunits by DEPe in BEAS-2B cells. By contrast, AhR-mediated regulation of CYP1A1 appears to be 
EGR1-independent. The exact way by which EGR1 may contribute to AhR-dependent induction of LAT1/CD98he in response to DEPe remains to be determined. EGR1 may be postulated to physically form a complex with AhR, which may in turn favor the binding of AhR/EGR 1 to the promoter of the responsive genes, as already demonstrated for the AhRdependent regulation of thrombospondin (Dabir et al., 2008). Further studies are likely required to investigate this hypothesis.

LAT1 induction by DEPe has functional consequences in BEAS-2B cells in term of amino acid transport, as demonstrated by the increased $\mathrm{BCH}$-inhibitable uptake of leucine in DEPe-exposed BEAS-2B cells when compared to untreated counterparts. Up-regulation of LAT1 activity has been associated with enhanced mTORC1 activity in various cell models (Nicklin et al., 2009; Sinclair et al., 2013). By contrast, LAT1-mediated enhanced accumulation of leucine failed to induce mTORC1 activity in DEPe-exposed BEAS-2B cells. The reason for such a lack of up-regulation is unclear, but could be linked to the high constitutional activity of mTORC1 in BEAS-2B cells, regardless of DEPe treatment.

MMP-2 was found to be up-regulated at both mRNA levels and activity level in DEPe-exposed BEAS-2B cells. MMP-2 mRNA up-regulation by DEPe required protein synthesis; it was also dependent on AhR-dependent CD98he induction by DEPe and on FAK activity. MMP-2 induction may therefore be considered as a secondary response to DEPe exposure, likely driven by the CD98hc/ $\beta 1$-integrin/FAK signaling cascade, that has previously been shown to participate to MMP-2 expression in HeLa cells (Santiago-Gomez et al., 2013). Besides FAK, the MAPK ERK, that commonly acts downstream the former kinase (Saleem et al., 2009), is also involved in MMP-2 induction by DEPe, because the ERK inhibitor U0126 fully prevented it; by contrast, a role for the PI3K/Akt pathway has to be discarded, because the PI3K/Akt inhibitor wortmannin had no effect. It is however noteworthy that we failed to clearly detect increased FAK or ERK phosphorylation in 
response to a 24-h exposure to DEPe in BEAS-2B cells, whereas MMP-2 mRNA was already induced by a 3.2-fold factor for this treatment time. In this context, it is noteworthy that early and transient inductions of ERK and FAK activities commonly occur in response to various types of stimuli (Li et al., 1997; Rosado et al., 2000), including exposure to DEPs-related PAHs (Lecureur et al., 2005; Castillo-Sanchez et al., 2013). This may be consistent with the hypothesis that DEPe only transiently induced FAK and ERK activity in BEAS-2B cells, as soon as a sufficient level of DEPe-mediated CD98hc induction was reached. The time of exposure to DEPe required for reaching this initial relevant induction of CD98hc can be hypothesized to be approximately in the range of $8-24 \mathrm{~h}$ according to data from time-course analysis of CD98hc protein regulation by DEPe (Fig. 2). We however failed to detect FAK or ERK activation in response to DEPe exposure for $4 \mathrm{~h}, 6 \mathrm{~h}, 8 \mathrm{~h}, 9 \mathrm{~h}, 10 \mathrm{~h}, 11 \mathrm{~h}, 12 \mathrm{~h}$ or $16 \mathrm{~h}$ (data not shown), which supports the hypothesis of a transient and fleeting activation of these kinases in response to DEPe. The exact DEPe treatment time required for getting minimal level of DEPe-induced CD98hc protein sufficient to activate the $\beta$-integrin/FAK/ERK pathway may be consequently likely uneasy to precisely determine. For summarizing (Fig. S6), DEPe is likely to first induce CD98hc expression in an AhR-dependent manner and then CD98hc, up-regulated by DEPe, may secondly induce MMP2 expression via FAK and ERK activation. DEPe-mediated up-regulation of CD98hc has therefore biological consequences, i.e., MMP-2 up-regulation.

The relevance of our in vitro findings to in vivo exposure to atmospheric DEPs constitutes probably a key-point that has to be clarified. In this context, it is noteworthy that the DEPe $\mathrm{EC}_{50}$ values up-regulating LAT1/CD98hc, that are around $0.2 \mu \mathrm{g} / \mathrm{mL}$, correspond to approximately $0.04 \mu \mathrm{g} / \mathrm{cm}^{2}$ equivalent DEP dose according to previous conversions of in vitro DEPe/DEP dose to DEP dose/unit surface area (Li et al., 2003). Importantly, such exposure levels are thought to be achieved in respiratory tracts for subjects exposed to DEPs-containing 
atmospheres (Li et al., 2003), thus underlining the fact that our in vitro exposure conditions may be close to environmental exposure situations. Humans exposed to atmospheric DEPs may therefore be hypothesized to exhibit increased level of LAT1/CD98hc expression in lung cells. This may in turn contribute to the toxicity of DEPs, notably to their carcinogenic effects, owing to the well-established implication of LAT1 and CD98hc in cancer promotion and progression, and, by this way, this may participate to the well-established overexpression of LAT1/CD98hc in lung cancers (Kaira et al., 2009). Carcinogenesis is however well-known to be a multistep process (Barrett, 1993). Therefore, it could be speculated that LAT1/CD98hc induction in response to DEPe may contribute to initiation of lung cancer and that LAT1/CD98hc overexpression becomes constitutive in later phases of carcinogenesis, through unknown mechanisms.

In summary, exposure to DEPe, used at concentrations relevant to environmental situations, was demonstrated to induce functional expression of the heterodimeric amino acid transporter LAT1/CD98hc in lung epithelial BEAS-2B cells in an AhR-dependent manner. Such an up-regulation may contribute to the toxicity of atmospheric DEPs, notably to their carcinogenic effects. 


\section{REFERENCES}

Andrieux, L., Langouet, S., Fautrel, A., Ezan, F., Krauser, J.A., Savouret, J.F., Guengerich, F.P., Baffet, G., Guillouzo, A., 2004. Aryl hydrocarbon receptor activation and cytochrome P450 1A induction by the mitogen-activated protein kinase inhibitor U0126 in hepatocytes. Mol Pharmacol 65, 934-943.

Barrett, J.C., 1993. Mechanisms of multistep carcinogenesis and carcinogen risk assessment. Environ Health Perspect 100, 9-20.

Bauvois, B., 2012. New facets of matrix metalloproteinases MMP-2 and MMP-9 as cell surface transducers: outside-in signaling and relationship to tumor progression. Biochim Biophys Acta 1, 29-36.

Castillo-Sanchez, R., Villegas-Comonfort, S., Galindo-Hernandez, O., Gomez, R., Salazar, E.P., 2013. Benzo-[a]-pyrene induces FAK activation and cell migration in MDAMB-231 breast cancer cells. Cell Biol Toxicol 29, 303-319.

Dabir, P., Marinic, T.E., Krukovets, I., Stenina, O.I., 2008. Aryl hydrocarbon receptor is activated by glucose and regulates the thrombospondin-1 gene promoter in endothelial cells. Circ Res 102, 1558-1565.

del Amo, E.M., Urtti, A., Yliperttula, M., 2008. Pharmacokinetic role of L-type amino acid transporters LAT1 and LAT2. Eur J Pharm Sci 35, 161-174.

Drummond, M.J., Glynn, E.L., Fry, C.S., Timmerman, K.L., Volpi, E., Rasmussen, B.B., 2010. An increase in essential amino acid availability upregulates amino acid transporter expression in human skeletal muscle. Am J Physiol Endocrinol Metab 298, 9.

Dunlop, E.A., Tee, A.R., 2009. Mammalian target of rapamycin complex 1: signalling inputs, substrates and feedback mechanisms. Cell Signal 21, 827-835. 
Elorza, A., Soro-Arnaiz, I., Melendez-Rodriguez, F., Rodriguez-Vaello, V., Marsboom, G., de Carcer, G., Acosta-Iborra, B., Albacete-Albacete, L., Ordonez, A., Serrano-Oviedo, L., Gimenez-Bachs, J.M., Vara-Vega, A., Salinas, A., Sanchez-Prieto, R., Martin del Rio, R., Sanchez-Madrid, F., Malumbres, M., Landazuri, M.O., Aragones, J., 2012. HIF2alpha acts as an mTORC1 activator through the amino acid carrier SLC7A5. Mol Cell 48, 681-691.

Fei, F., Li, X., Xu, L., Li, D., Zhang, Z., Guo, X., Yang, H., Chen, Z., Xing, J., 2014. CD147CD98hc complex contributes to poor prognosis of non-small cell lung cancer patients through promoting cell proliferation via the PI3K/Akt signaling pathway. Ann Surg Oncol 21, 4359-4368.

Feral, C.C., Nishiya, N., Fenczik, C.A., Stuhlmann, H., Slepak, M., Ginsberg, M.H., 2005. CD98hc (SLC3A2) mediates integrin signaling. Proc Natl Acad Sci U S A 102, $355-$ 360.

Fotiadis, D., Kanai, Y., Palacin, M., 2013. The SLC3 and SLC7 families of amino acid transporters. Mol Aspects Med 34, 139-158.

Fuchs, B.C., Bode, B.P., 2005. Amino acid transporters ASCT2 and LAT1 in cancer: partners in crime? Semin Cancer Biol 15, 254-266.

Gouge, B., Ries, F.J., Dowlatabadi, H., 2010. Spatial distribution of diesel transit bus emissions and urban populations: implications of coincidence and scale on exposure. Environ Sci Technol 44, 7163-7168.

Hankinson, O., 2005. Role of coactivators in transcriptional activation by the aryl hydrocarbon receptor. Arch Biochem Biophys 433, 379-386.

Hartz, A.M., Bauer, B., Block, M.L., Hong, J.S., Miller, D.S., 2008. Diesel exhaust particles induce oxidative stress, proinflammatory signaling, and P-glycoprotein up-regulation at the blood-brain barrier. Faseb J 22, 2723-2733. 
Hughes, T.J., Lewtas, J., Claxton, L.D., 1997. Development of a standard reference material for diesel mutagenicity in the Salmonella plate incorporation assay. Mutat Res 391, 243-258.

Imai, H., Kaira, K., Oriuchi, N., Shimizu, K., Tominaga, H., Yanagitani, N., Sunaga, N., Ishizuka, T., Nagamori, S., Promchan, K., Nakajima, T., Yamamoto, N., Mori, M., Kanai, Y., 2010. Inhibition of L-type amino acid transporter 1 has antitumor activity in non-small cell lung cancer. Anticancer Res 30, 4819-4828.

Imai, H., Kaira, K., Oriuchi, N., Yanagitani, N., Sunaga, N., Ishizuka, T., Kanai, Y., Endou, H., Nakajima, T., Mori, M., 2009. L-type amino acid transporter 1 expression is a prognostic marker in patients with surgically resected stage I non-small cell lung cancer. Histopathology 54, 804-813.

Jaguin, M., Fardel, O., Lecureur, V., 2015. AhR-dependent secretion of PDGF-BB by human classically activated macrophages exposed to DEP extracts stimulates lung fibroblast proliferation. Toxicol Appl Pharmacol 285, 170-178.

Kaira, K., Oriuchi, N., Imai, H., Shimizu, K., Yanagitani, N., Sunaga, N., Hisada, T., Ishizuka, T., Kanai, Y., Nakajima, T., Mori, M., 2009. Prognostic significance of Ltype amino acid transporter 1 (LAT1) and 4F2 heavy chain (CD98) expression in stage I pulmonary adenocarcinoma. Lung Cancer 66, 120-126.

Kaira, K., Oriuchi, N., Imai, H., Shimizu, K., Yanagitani, N., Sunaga, N., Hisada, T., Kawashima, O., Kamide, Y., Ishizuka, T., Kanai, Y., Nakajima, T., Mori, M., 2010. Prognostic significance of L-type amino acid transporter 1 (LAT1) and 4F2 heavy chain (CD98) expression in surgically resectable stage III non-small cell lung cancer. Exp Ther Med 1, 799-808.

Kaira, K., Oriuchi, N., Imai, H., Shimizu, K., Yanagitani, N., Sunaga, N., Hisada, T., Tanaka, S., Ishizuka, T., Kanai, Y., Endou, H., Nakajima, T., Mori, M., 2008. 1-type amino 
acid transporter 1 and CD98 expression in primary and metastatic sites of human neoplasms. Cancer Sci 99, 2380-2386.

Kanai, Y., Segawa, H., Miyamoto, K., Uchino, H., Takeda, E., Endou, H., 1998. Expression cloning and characterization of a transporter for large neutral amino acids activated by the heavy chain of 4F2 antigen (CD98). J Biol Chem 273, 23629-23632.

Kawajiri, K., Fujii-Kuriyama, Y., 2007. Cytochrome P450 gene regulation and physiological functions mediated by the aryl hydrocarbon receptor. Arch Biochem Biophys 464, 207-212.

Kim, S.H., Henry, E.C., Kim, D.K., Kim, Y.H., Shin, K.J., Han, M.S., Lee, T.G., Kang, J.K., Gasiewicz, T.A., Ryu, S.H., Suh, P.G., 2006. Novel compound 2-methyl-2H-pyrazole3-carboxylic acid (2-methyl-4-o-tolylazo-phenyl)-amide (CH-223191) prevents 2,3,7,8-TCDD-induced toxicity by antagonizing the aryl hydrocarbon receptor. Mol Pharmacol 69, 1871-1878.

Kinne, A., Schulein, R., Krause, G., 2011. Primary and secondary thyroid hormone transporters. Thyroid Res 3, 1756-6614.

Koike, E., Hirano, S., Shimojo, N., Kobayashi, T., 2002. cDNA microarray analysis of gene expression in rat alveolar macrophages in response to organic extract of diesel exhaust particles. Toxicol Sci 67, 241-246.

Laplante, M., Sabatini, D.M., 2012. mTOR signaling in growth control and disease. Cell 149, 274-293.

Le Vee, M., Jouan, E., Fardel, O., 2010. Involvement of aryl hydrocarbon receptor in basal and 2,3,7,8-tetrachlorodibenzo-p-dioxin-induced expression of target genes in primary human hepatocytes. Toxicol In Vitro 24, 1775-1781. 
Le Vee, M., Jouan, E., Noel, G., Stieger, B., Fardel, O., 2015a. Polarized location of SLC and ABC drug transporters in monolayer-cultured human hepatocytes. Toxicol In Vitro 29, 938-946.

Le Vee, M., Jouan, E., Stieger, B., Lecureur, V., Fardel, O., 2015b. Regulation of human hepatic drug transporter activity and expression by diesel exhaust particle extract. PLoS One 10.

Le Vee, M., Kolasa, E., Jouan, E., Collet, N., Fardel, O,, 2014. Differentiation of human placental BeWo cells by the environmental contaminant benzo(a)pyrene. Chem Biol Interact 210, 1-11.

Le Vee, M., Lecureur, V., Stieger, B., Fardel, O., 2009. Regulation of drug transporter expression in human hepatocytes exposed to the proinflammatory cytokines tumor necrosis factor-alpha or interleukin-6. Drug Metab Dispos 37, 685-693.

Lecureur, V., Ferrec, E.L., N'Diaye, M., Vee, M.L., Gardyn, C., Gilot, D., Fardel, O., 2005. ERK-dependent induction of TNFalpha expression by the environmental contaminant benzo(a)pyrene in primary human macrophages. FEBS Lett 579, 1904-1910.

Lee, J.H., Kim, K.T., 2004. Induction of cyclin-dependent kinase 5 and its activator p35 through the extracellular-signal-regulated kinase and protein kinase A pathways during retinoic-acid mediated neuronal differentiation in human neuroblastoma SK-NBE(2)C cells. J Neurochem 91, 634-647.

Li, N., Hao, M., Phalen, R.F., Hinds, W.C., Nel, A.E., 2003. Particulate air pollutants and asthma. A paradigm for the role of oxidative stress in PM-induced adverse health effects. Clin Immunol 109, 250-265.

Li, S., Kim, M., Hu, Y.L., Jalali, S., Schlaepfer, D.D., Hunter, T., Chien, S., Shyy, J.Y., 1997. Fluid shear stress activation of focal adhesion kinase. Linking to mitogen-activated protein kinases. J Biol Chem 272, 30455-30462. 
Machala, M., Vondracek, J., Blaha, L., Ciganek, M., Neca, J.V., 2001. Aryl hydrocarbon receptor-mediated activity of mutagenic polycyclic aromatic hydrocarbons determined using in vitro reporter gene assay. Mutat Res 497, 49-62.

Macoch, M., Morzadec, C., Genard, R., Pallardy, M., Kerdine-Romer, S., Fardel, O., Vernhet, L., 2015. Nrf2-dependent repression of interleukin-12 expression in human dendritic cells exposed to inorganic arsenic. Free Radic Biol Med 11, 00044-00041.

Manoury, B., Nenan, S., Leclerc, O., Guenon, I., Boichot, E., Planquois, J.M., Bertrand, C.P., Lagente, V., 2005. The absence of reactive oxygen species production protects mice against bleomycin-induced pulmonary fibrosis. Respir Res 6, 11.

Nicklin, P., Bergman, P., Zhang, B., Triantafellow, E., Wang, H., Nyfeler, B., Yang, H., Hild, M., Kung, C., Wilson, C., Myer, V.E., MacKeigan, J.P., Porter, J.A., Wang, Y.K., Cantley, L.C., Finan, P.M., Murphy, L.O., 2009. Bidirectional transport of amino acids regulates mTOR and autophagy. Cell 136, 521-534.

Ovrevik, J., Arlt, V.M., Oya, E., Nagy, E., Mollerup, S., Phillips, D.H., Lag, M., Holme, J.A., 2010. Differential effects of nitro-PAHs and amino-PAHs on cytokine and chemokine responses in human bronchial epithelial BEAS-2B cells. Toxicol Appl Pharmacol 242, $270-280$.

Palacin, M., Kanai, Y., 2004. The ancillary proteins of HATs: SLC3 family of amino acid transporters. Pflugers Arch 447, 490-494.

Puga, A., Ma, C., Marlowe, J.L., 2009. The aryl hydrocarbon receptor cross-talks with multiple signal transduction pathways. Biochem Pharmacol 77, 713-722.

Rosado, J.A., Salido, G.M., Garcia, L.J., 2000. Activation of m3 muscarinic receptors induces rapid tyrosine phosphorylation of $\mathrm{p} 125(\mathrm{FAK}), \mathrm{p} 130$ (cas), and paxillin in rat pancreatic acini. Arch Biochem Biophys 377, 85-94. 
Saleem, S., Li, J., Yee, S.P., Fellows, G.F., Goodyer, C.G., Wang, R., 2009. beta1 integrin/FAK/ERK signalling pathway is essential for human fetal islet cell differentiation and survival. J Pathol 219, 182-192.

Santiago-Gomez, A., Barrasa, J.I., Olmo, N., Lecona, E., Burghardt, H., Palacin, M., Lizarbe, M.A., Turnay, J., 2013. 4F2hc-silencing impairs tumorigenicity of HeLa cells via modulation of galectin-3 and beta-catenin signaling, and MMP-2 expression. Biochim Biophys Acta 9, 4.

Sarkar, D., Kambe, F., Hirata, A., Iseki, A., Ohmori, S., Seo, H., 1999. Expression of E16/CD98LC/hLAT1 is responsive to 2,3,7,8-tetrachlorodibenzo-p-dioxin. FEBS Lett $462,430-434$

Sawai, H., Okada, Y., Funahashi, H., Matsuo, Y., Takahashi, H., Takeyama, H., Manabe, T., 2005. Activation of focal adhesion kinase enhances the adhesion and invasion of pancreatic cancer cells via extracellular signal-regulated kinase-1/2 signaling pathway activation. Mol Cancer 4, 37.

Schwarze, P.E., Totlandsdal, A.I., Lag, M., Refsnes, M., Holme, J.A., Ovrevik, J., 2013. Inflammation-related effects of diesel engine exhaust particles: studies on lung cells in vitro. Biomed Res Int 685142, 14.

Sinclair, L.V., Rolf, J., Emslie, E., Shi, Y.B., Taylor, P.M., Cantrell, D.A., 2013. Control of amino-acid transport by antigen receptors coordinates the metabolic reprogramming essential for T cell differentiation. Nat Immunol 14, 500-508.

Slack-Davis, J.K., Martin, K.H., Tilghman, R.W., Iwanicki, M., Ung, E.J., Autry, C., Luzzio, M.J., Cooper, B., Kath, J.C., Roberts, W.G., Parsons, J.T., 2007. Cellular characterization of a novel focal adhesion kinase inhibitor. J Biol Chem 282, 14845 14852.

Sorg, O., 2014. AhR signalling and dioxin toxicity. Toxicol Lett 230, 225-233. 
Soulez, M., Parker, M.G., 2001. Identification of novel oestrogen receptor target genes in human ZR75-1 breast cancer cells by expression profiling. J Mol Endocrinol 27, 259274.

Taylor, P.M., 2014. Role of amino acid transporters in amino acid sensing. Am J Clin Nutr 99, 27.

Toth, M., Sohail, A., Fridman, R., 2012. Assessment of gelatinases (MMP-2 and MMP-9) by gelatin zymography. Methods Mol Biol 878, 121-135.

van Grevenynghe, J., Rion, S., Le Ferrec, E., Le Vee, M., Amiot, L., Fauchet, R., Fardel, O., 2003. Polycyclic aromatic hydrocarbons inhibit differentiation of human monocytes into macrophages. J Immunol 170, 2374-2381.

van Grevenynghe, J., Sparfel, L., Le Vee, M., Gilot, D., Drenou, B., Fauchet, R., Fardel, O., 2004. Cytochrome P450-dependent toxicity of environmental polycyclic aromatic hydrocarbons towards human macrophages. Biochem Biophys Res Commun 317, 708-716.

Vermeulen, R., Silverman, D.T., Garshick, E., Vlaanderen, J., Portengen, L., Steenland, K., 2014. Exposure-response estimates for diesel engine exhaust and lung cancer mortality based on data from three occupational cohorts. Environ Health Perspect 122, 172-177.

Verrey, F., 2003. System L: heteromeric exchangers of large, neutral amino acids involved in directional transport. Pflugers Arch 445, 529-533.

Wang, Q., Holst, J., 2015. L-type amino acid transport and cancer: targeting the mTORC1 pathway to inhibit neoplasia. Am J Cancer Res 5, 1281-1294.

Wichmann, H.E., 2007. Diesel exhaust particles. Inhal Toxicol 1, 241-244.

Xu, S., Weerachayaphorn, J., Cai, S.Y., Soroka, C.J., Boyer, J.L., 2010. Aryl hydrocarbon receptor and NF-E2-related factor 2 are key regulators of human MRP4 expression. Am J Physiol Gastrointest Liver Physiol 299, 15. 


\section{LEGENDS TO FIGURES}

Fig. 1. Induction of LAT1/CD98hc mRNA expression by DEPe.

BEAS-2B cells were either untreated or exposed to (A) $5 \mu \mathrm{g} / \mathrm{mL}$ DEPe for various lengths of time (from $8 \mathrm{~h}$ to $48 \mathrm{~h}$ ), (B) to various DEPe concentrations (from 0.01 to $10 \mu \mathrm{g} / \mathrm{mL}$ ) for $24 \mathrm{~h}$ or (C) to $5 \mu \mathrm{g} / \mathrm{mL}$ DEPe for $24 \mathrm{~h}$. (A, B) LAT1, CD98hc and (C) other amino acid transporter subunit mRNA expressions were next determined by RT-qPCR. Data are expressed (A, B) as fold induction factor comparatively to mRNA levels found in untreated cells or (C) in arbitrary units, as described in Materials and Methods; they are the means \pm SEM of three independent assays. (A, C) *, p<0.05 when compared to untreated cells.

Fig. 2. Induction of LAT1/CD98hc protein expression by DEPe.

BEAS-2B cells were either untreated or exposed to $5 \mu \mathrm{g} / \mathrm{mL}$ DEPe for various lengths of time (from $8 \mathrm{~h}$ to $48 \mathrm{~h}$ ). LAT1 and CD98hc contents were then determined by Western-blot analysis; HSC70 content was analyzed in parallel as a gel loading control. (A) A representative blot is shown for LAT1 and CD98hc. (B) LAT1- and CD98hc-related stained bands were quantified by densitometric analysis and expressed relatively to expression level found in untreated cells, arbitrarily set at the value of 100\%, after normalization to HSC70 content. Values are the means \pm SEM of three independent assays. ${ }^{*}, \mathrm{p}<0.05$ when compared to untreated cells.

Fig. 3 Effects of actinomycin D and cycloheximide on DEPe-mediated up-regulation of LAT1/CD98hc mRNA expression.

BEAS-2B cells were either untreated or exposed to $5 \mu \mathrm{g} / \mathrm{mL}$ DEPe, $1 \mu \mathrm{g} / \mathrm{mL}$ actinomycin D (actino D) or $5 \mu \mathrm{g} / \mathrm{mL}$ cycloheximide $(\mathrm{CHX})$ or co-exposed to DEPe/actinomycin D or 
DEPe/cycloheximide for $8 \mathrm{~h}$. LAT1 and CD98hc mRNA expressions were next determined by RT-qPCR. Data are expressed as fold induction factor comparatively to mRNA levels found in untreated cells and are the means \pm SEM of three independent assays. *, p $<0.05$ when compared to untreated cells.

Fig. 4. Effects of various environmental aryl hydrocarbons on LAT1/CD98he mRNA expression. BEAS-2B cells were either untreated or exposed to $5 \mu \mathrm{g} / \mathrm{mL}$ DEPe, $10 \mu \mathrm{M}$ benzo(a)pyrene (B(a)P), $10 \mu \mathrm{M}$ benzanthracene (BZA), $10 \mu \mathrm{M}$ benzo(e)pyrene (B(e)P), 10 $\mu \mathrm{M}$ 1-nitropyrene (1-NP), $10 \mu \mathrm{M}$ chrysene or $10 \mathrm{nM}$ TCDD. CYP1A1, LAT1 and CD98hc mRNA expressions were next determined by RT-qPCR. Data are expressed as fold induction factor comparatively to mRNA levels found in untreated cells and are the means \pm SEM of at least three independent assays. ${ }^{*}, \mathrm{p}<0.05$ when compared to untreated cells.

Fig. 5. Effects of AhR inhibition or silencing on DEPe-mediated LAT1/CD98hc mRNA expression.

(A) BEAS-2B cells were either untreated or exposed to $5 \mu \mathrm{g} / \mathrm{mL}$ DEPe, in the absence or presence of the AhR antagonist $\mathrm{CH}-223191$, used at $3 \mu \mathrm{M}$, for $8 \mathrm{~h}$. (B) BEAS-2B cells, transfected by siRNAs against AhR (si AhR) or by control non-targeting siRNAs (si NT), were either untreated or exposed to $5 \mu \mathrm{g} / \mathrm{mL}$ DEPe for $8 \mathrm{~h}$. (A, B) LAT1, CD98hc and CYP1A1 mRNA expressions were next determined by RT-qPCR. Data are expressed as foldinduction factor comparatively to mRNA levels found in untreated cells and are the means $\underline{ \pm}$ SEM of at least three independent assays. * ${ }^{*}<0.05$.

Fig. 6. Effects of EGR1 down-regulation on DEPe-mediated LAT1/CD98he mRNA expression. 
(A) BEAS-2B cells were transfected by siRNAs against EGR1 (si EGR1) or by control nontargeting siRNAs (si NT). EGR1 protein content in cell lysates was then determined by Western-blot analysis; data shown are representative of three independent experiments. (B) siRNA-transfected BEAS-2B cells were either untreated or exposed to $5 \mu \mathrm{g} / \mathrm{mL}$ DEPe for $8 \mathrm{~h}$. LAT1, CD98hc and CYP1A1 mRNA expressions were next determined by RT-qPCR. Data are expressed as fold-induction factor comparatively to mRNA levels found in untreated cells and are the means \pm SEM of at least three independent assays. (C) BEAS-2B cells were either untreated or exposed to $10 \mu \mathrm{M}$ roscovitine for $2 \mathrm{~h}$. EGR1 protein content in nuclei extracts was then determined by Western-blot analysis; data shown are representative of three independent experiments. (D) BEAS-2B cells, previously exposed or not to $10 \mu \mathrm{M}$ roscovitine for $8 \mathrm{~h}$, were additionally either untreated or treated by $5 \mu \mathrm{g} / \mathrm{mL}$ DEPe for $8 \mathrm{~h}$. LAT1, CD98hc and CYP1A1 mRNA expressions were next determined by RT-qPCR. Data are expressed as fold-induction factor comparatively to mRNA levels found in untreated cells and are the means \pm SEM of at least three independent assays. $(B, D) *, p<0.05$. NS, not statistically significant.

Fig. 7. Effects of DEPe on LAT1 and mTORC1 activity.

(A) BEAS-2B cells, either untreated or treated by $5 \mu \mathrm{g} / \mathrm{mL}$ DEPe for $48 \mathrm{~h}$, were incubated with $0.69 \mathrm{nM} \mathrm{L}-\left[4,5-{ }^{3} \mathrm{H}\right]$ leucine for $5 \mathrm{~min}$ in the absence or presence of $1 \mathrm{mM} \mathrm{BCH}$. Intracellular accumulation of leucine was then determined by scintillation counting. Data are expressed as \% of intracellular uptake of leucine in control untreated cells and are the means \pm SEM of three independent assays. ${ }^{*}, \mathrm{p}<0.05$. (B) BEAS-2B cells were either untreated or treated by $5 \mu \mathrm{g} / \mathrm{mL}$ DEPe in the absence or presence of $100 \mathrm{nM}$ rapamycin (rapa) for 24 or 48 
h. Phospho-p70S6K, total-p70S6K, phospho-S6 and total-S6 contents were then determined by Western-blot analysis; data shown are representative of three independent experiments.

Fig. 8. CD98hc-dependent induction of MMP-2 expression by DEPe.

(A, B) BEAS-2B cells were either untreated or exposed to $5 \mu \mathrm{g} / \mathrm{mL}$ DEPe for various lengths of time (from $8 \mathrm{~h}$ to $48 \mathrm{~h}$ ). (A) MMP-2 mRNA expression was next determined by RT-qPCR. Data are expressed as fold induction factor comparatively to mRNA levels found in untreated cells and are the means \pm SEM of three independent assays. (B) Gelatinase activity of MMP-2 was analyzed as described in Materials and Methods. Data shown are representative of three independent experiments. (C) BEAS-2B cells were either untreated or exposed to $5 \mu \mathrm{g} / \mathrm{mL}$ DEPe for $24 \mathrm{~h}$ in the absence or presence of $5 \mu \mathrm{g} / \mathrm{mL}$ cycloheximide (CHX). MMP-2 mRNA expression was next determined by RT-qPCR. Data are expressed as fold induction factor comparatively to mRNA levels found in untreated cells and are the means \pm SEM of three independent assays. *, $\mathrm{p}<0.05$. (D) BEAS-2B cells, transfected by siRNAs against CD98hc (si CD98hc) or by control non-targeting siRNAs (si NT), were either untreated or exposed to $5 \mu \mathrm{g} / \mathrm{mL}$ DEPe for $24 \mathrm{~h}$. CD98hc, MMP-2 and CYP1A1 mRNA expressions were next determined by RT-qPCR. Data are expressed as fold induction factor comparatively to mRNA levels found in untreated cells and are the means \pm SEM of at least three independent assays. *, $\mathrm{p}<0.05$. NS, not statistically significant.

Fig. 9. Effects of FAK and ERK inhibition on DEPe-mediated up-regulation of MMP-2.

BEAS-2B cells were either untreated or exposed to $5 \mu \mathrm{g} / \mathrm{mL}$ DEPe for $24 \mathrm{~h}$, in the absence or presence of (A) the FAK inhibitor PF-573228, used at $1 \mu \mathrm{M}$, or (B) the ERK inhibitor U0126, used at $5 \mu \mathrm{M}$. MMP-2, CD98hc and CYP1A1 mRNA expressions were next determined by 
RT-qPCR. Data are expressed as fold induction factor comparatively to mRNA levels found in untreated cells and are the means \pm SEM of at least three independent assays. ${ }^{*}, p<0.05$. NS, not statistically significant. 

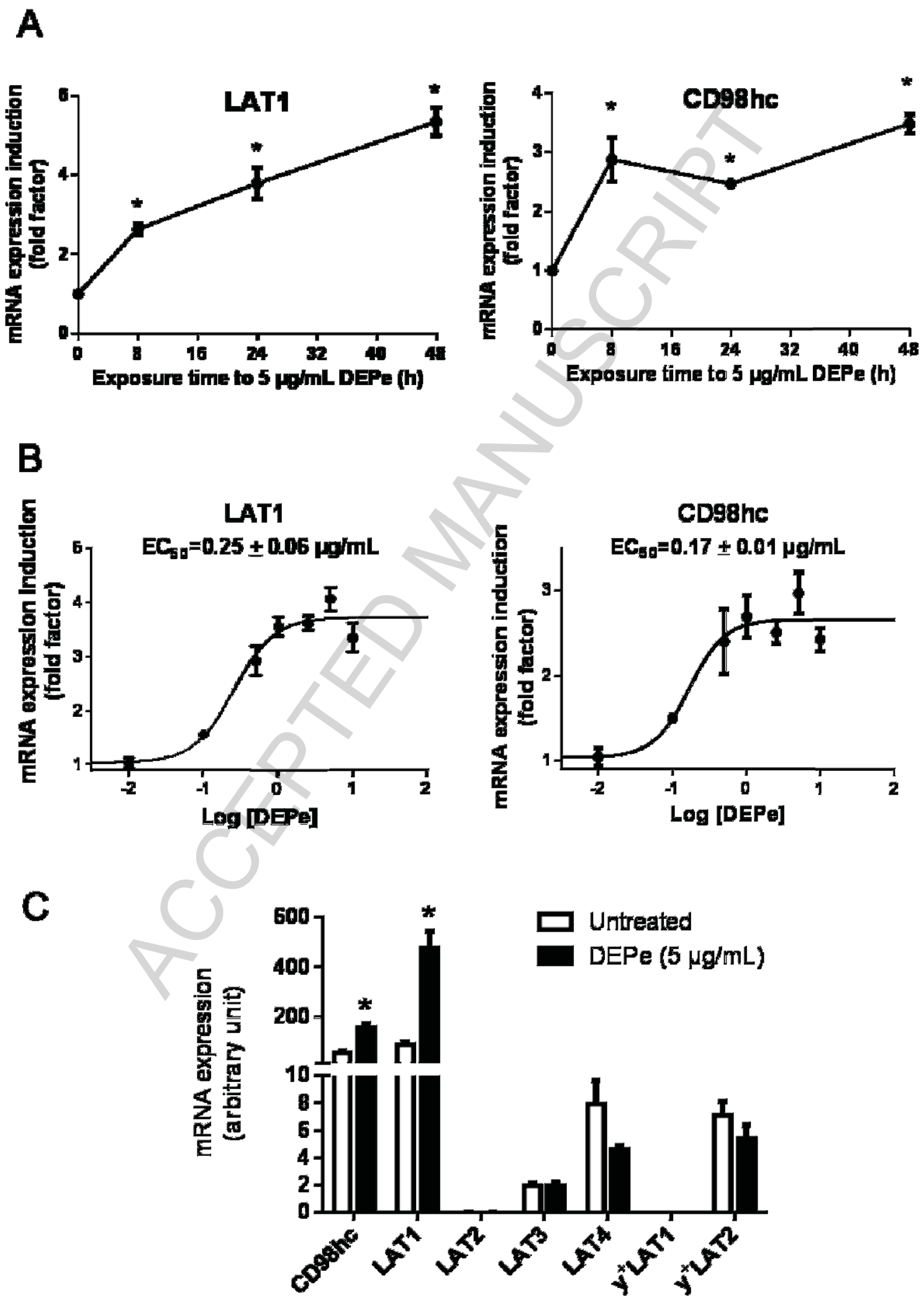

Fig. 1 
A

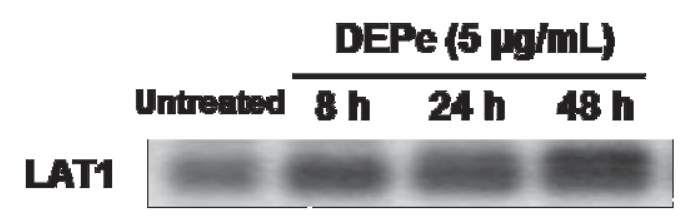

Hsc70

B

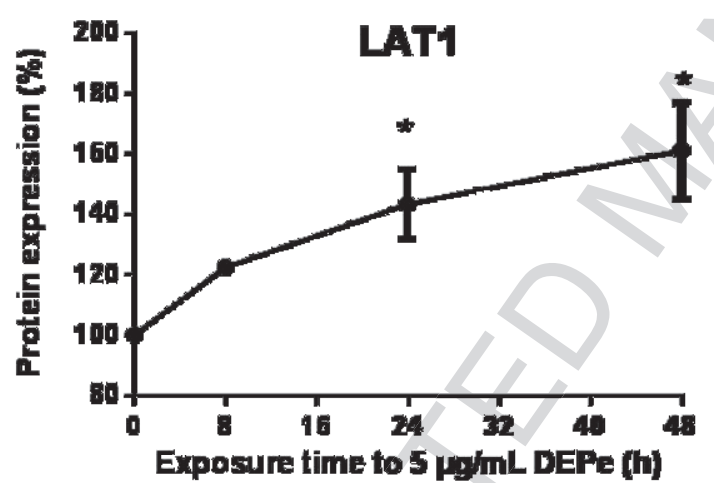

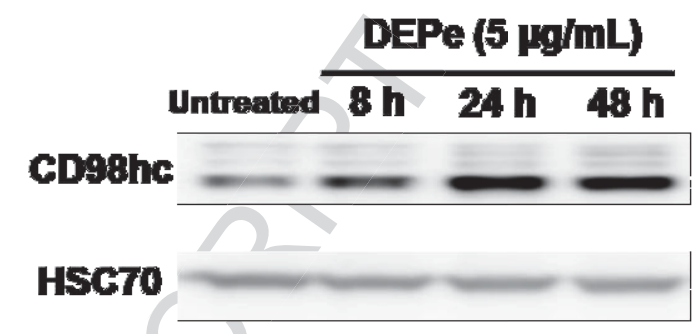

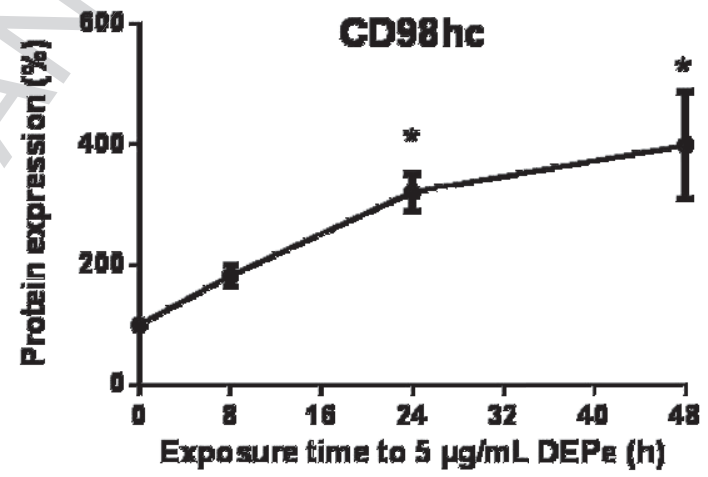

Fig. 2 


\section{LAT1}

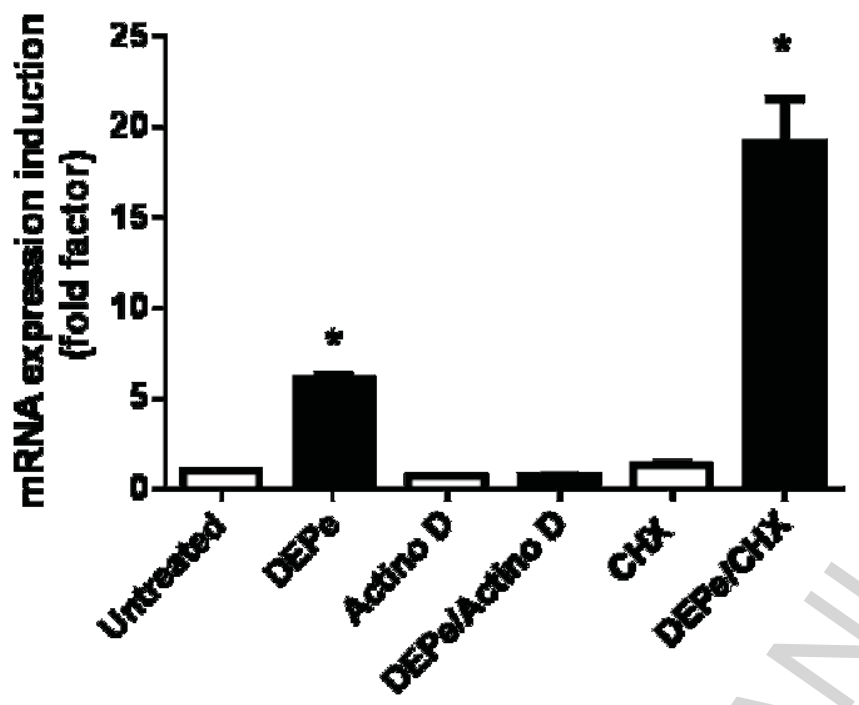

CDg8he

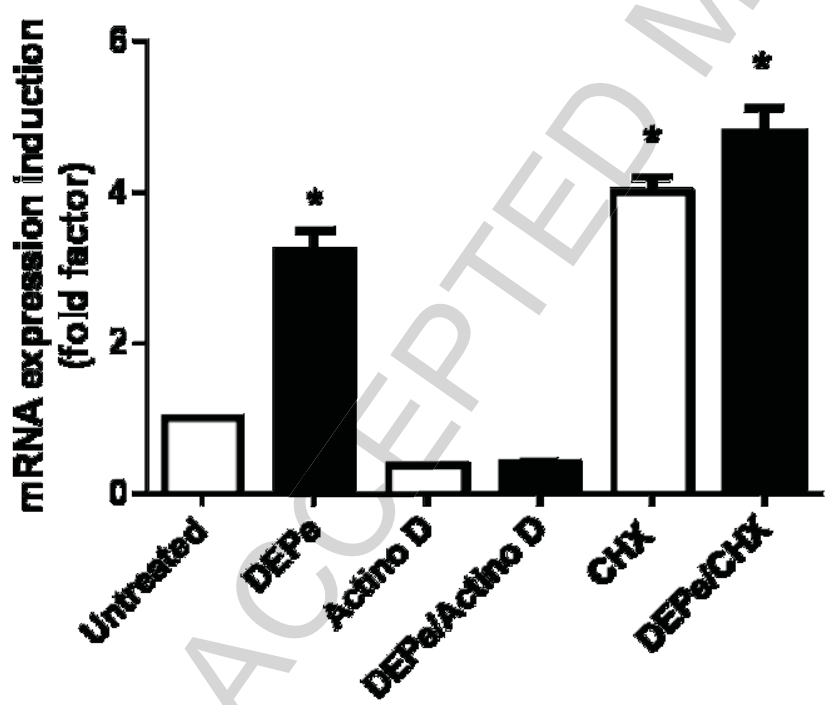

Fig. 3 

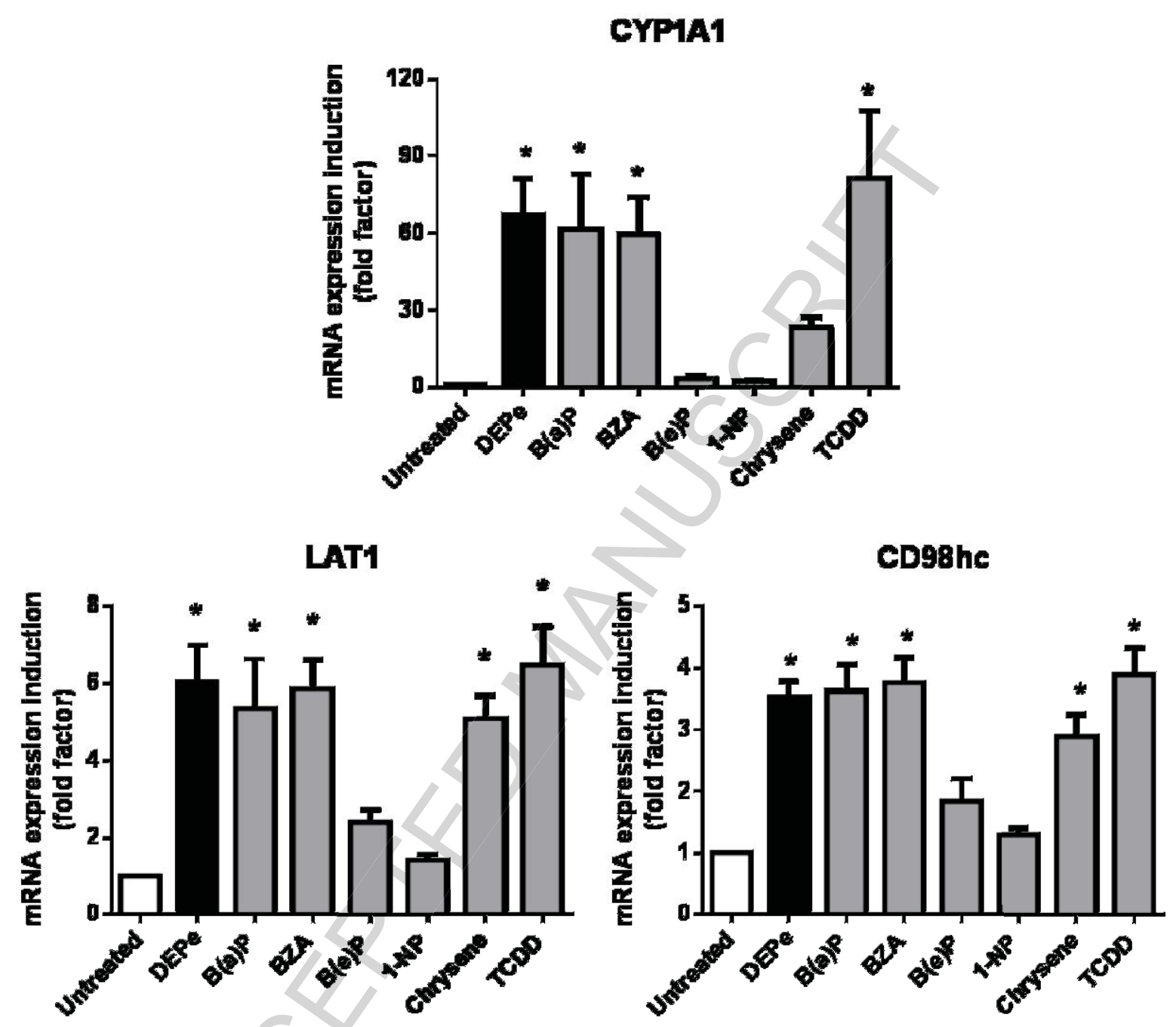

Fig. 4 
A
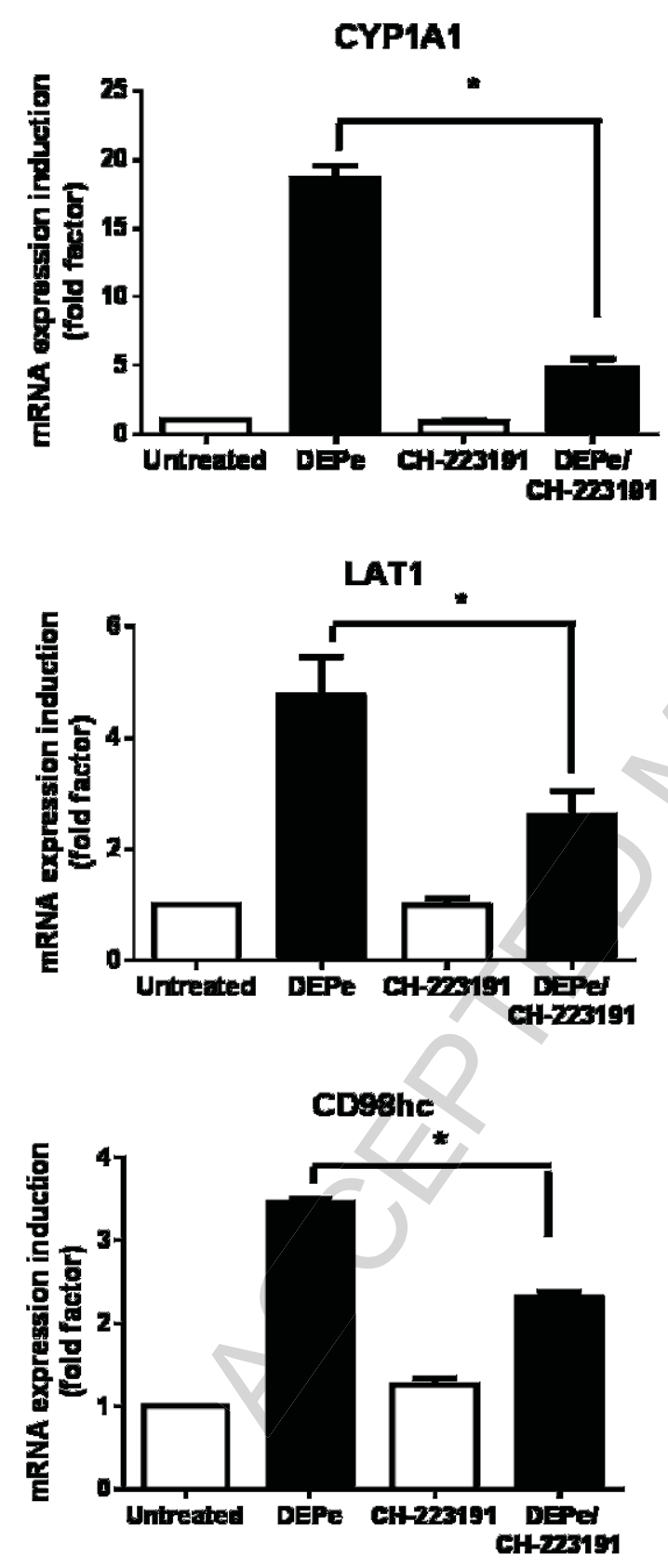

B
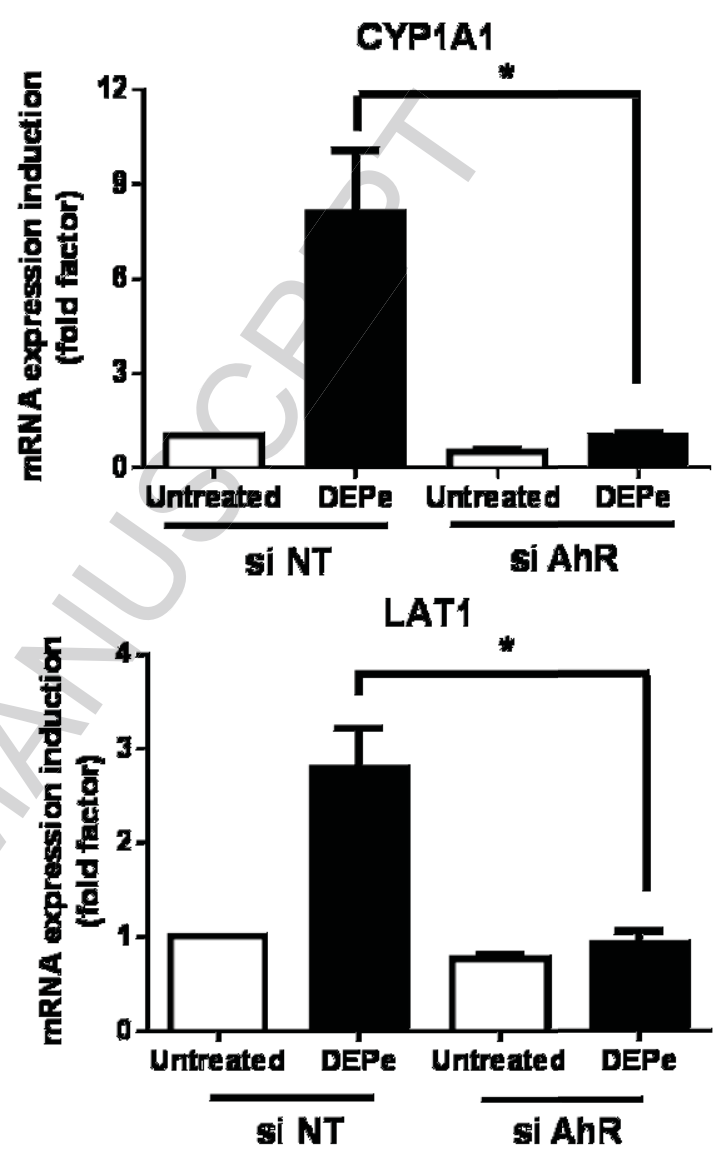

CDg8he

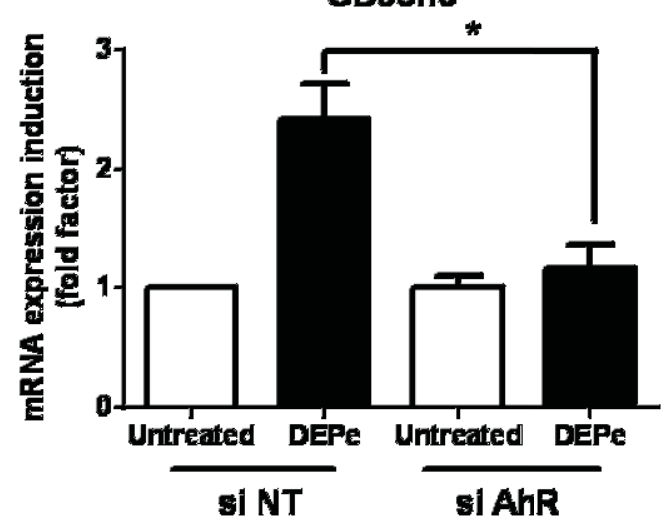

Fig. 5 


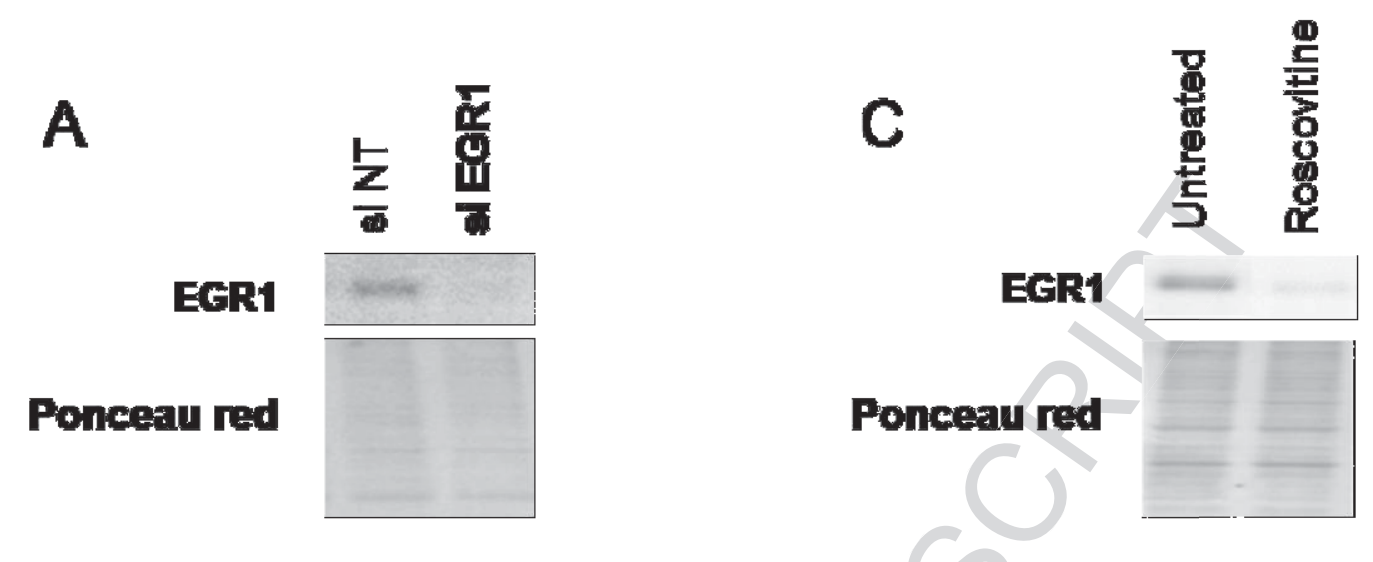

B

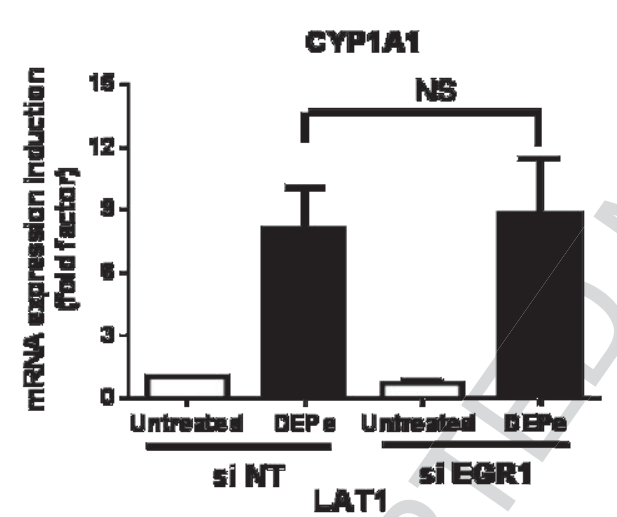

D
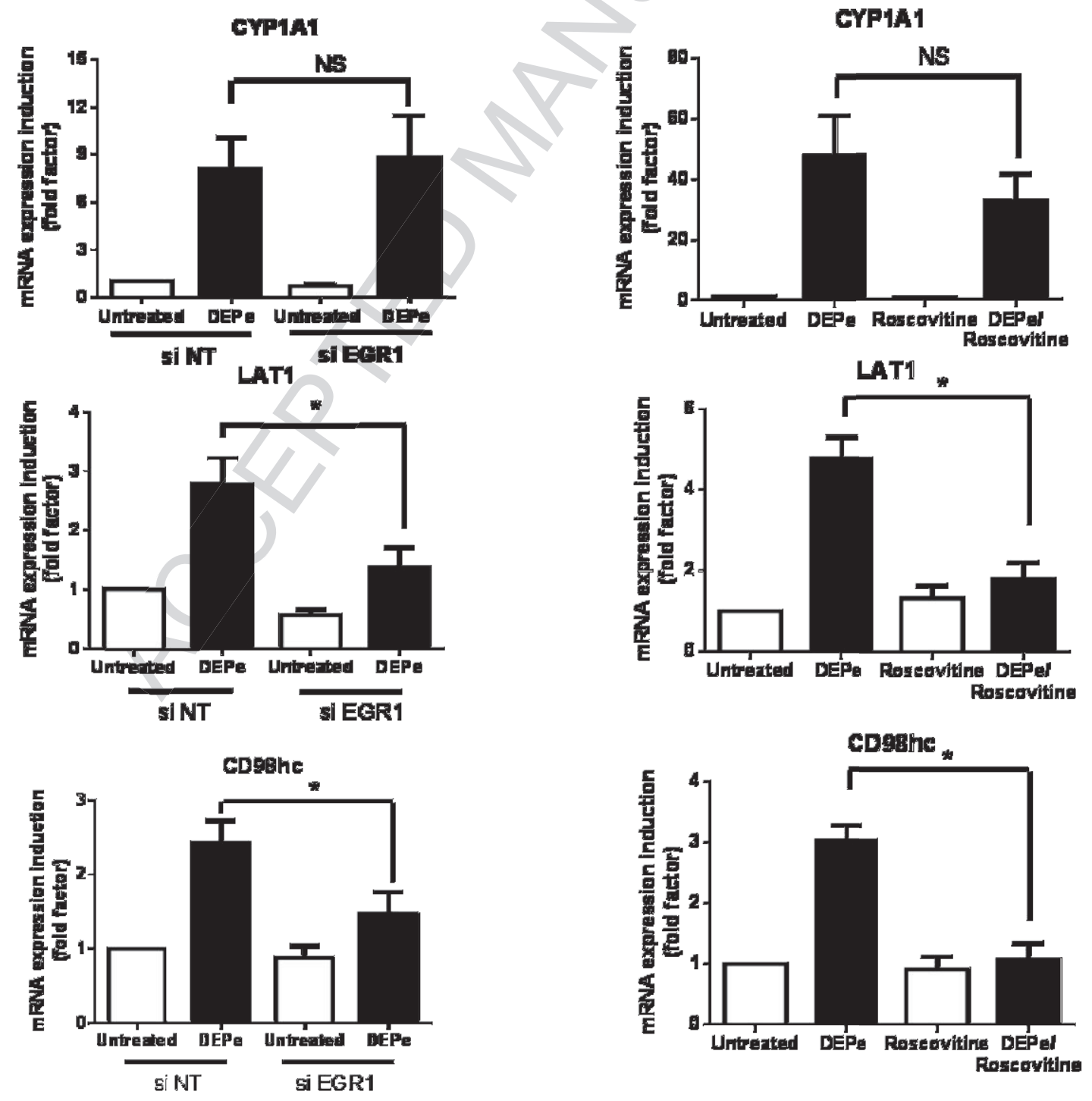

Fig. 6 
A

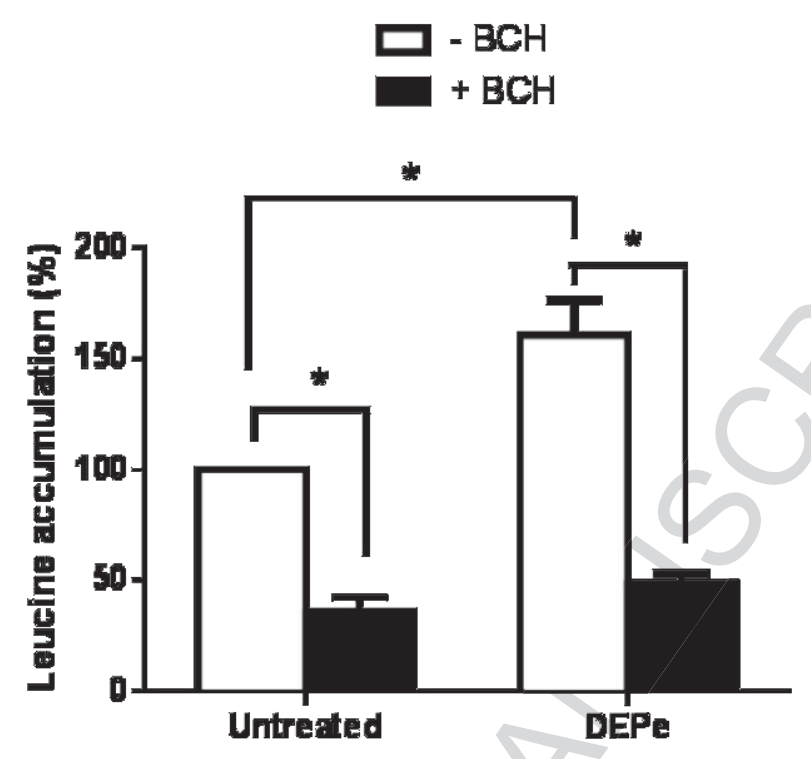

B

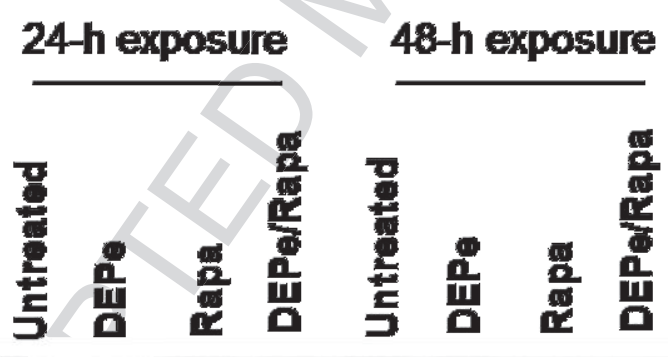

Phospho-p70sak

Totalp70s6K

Phospho-s6

Total-s6

Fig. 7 
A

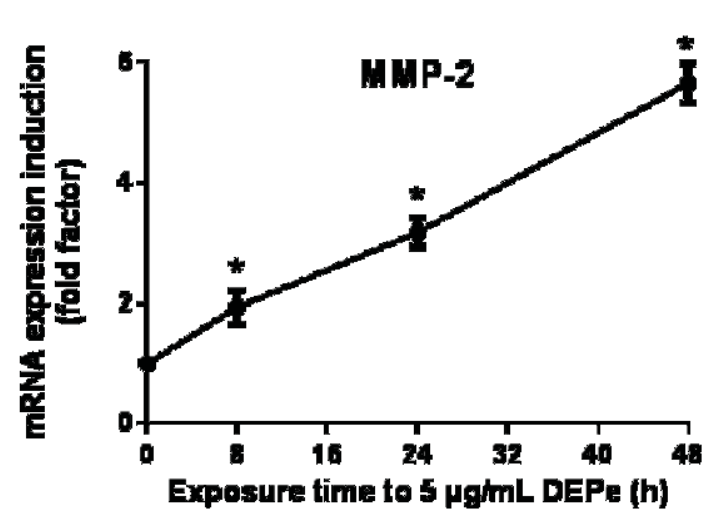

B

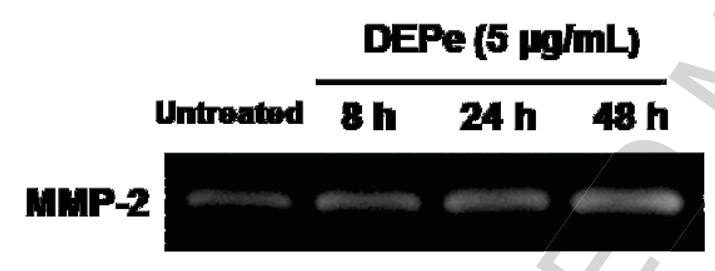

C

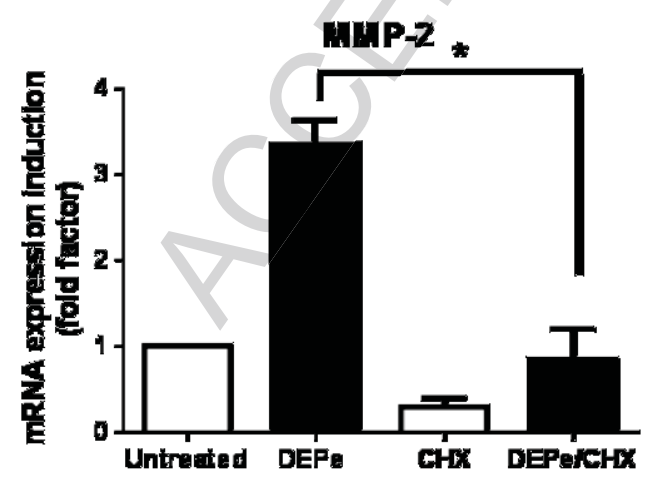

D

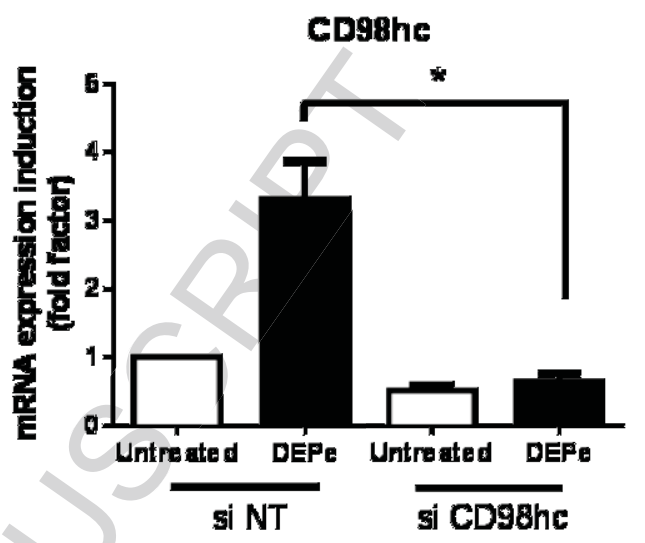

MAP-2

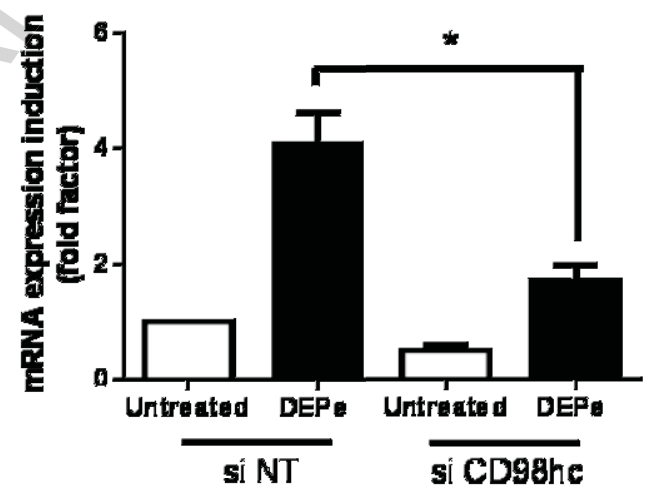

CYP1A1

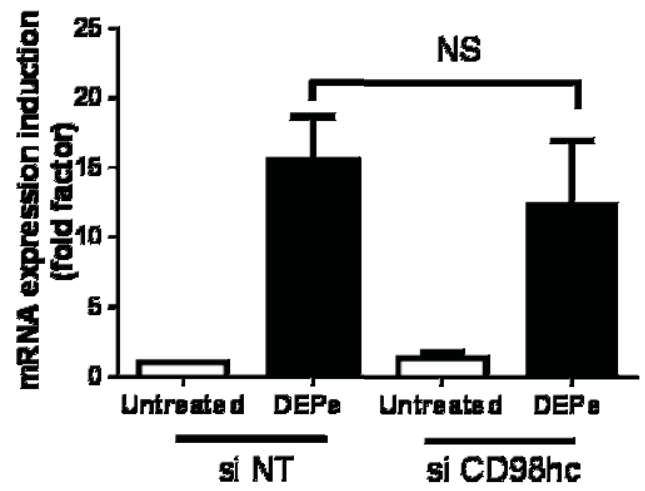

Fig. 8 
A

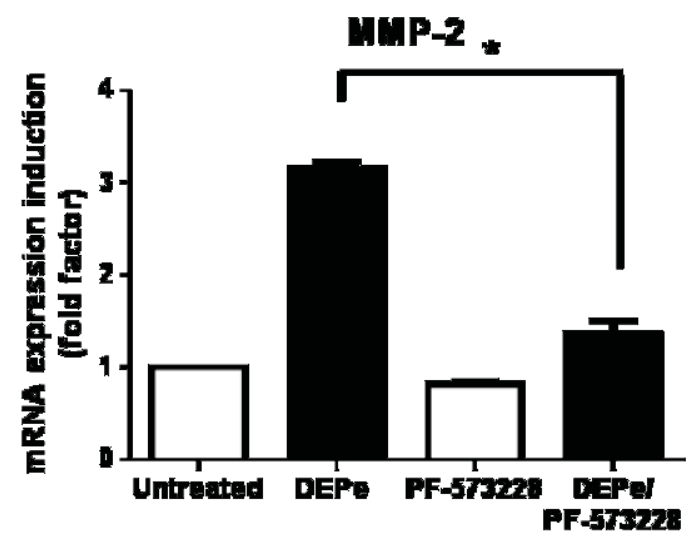

CDg8he

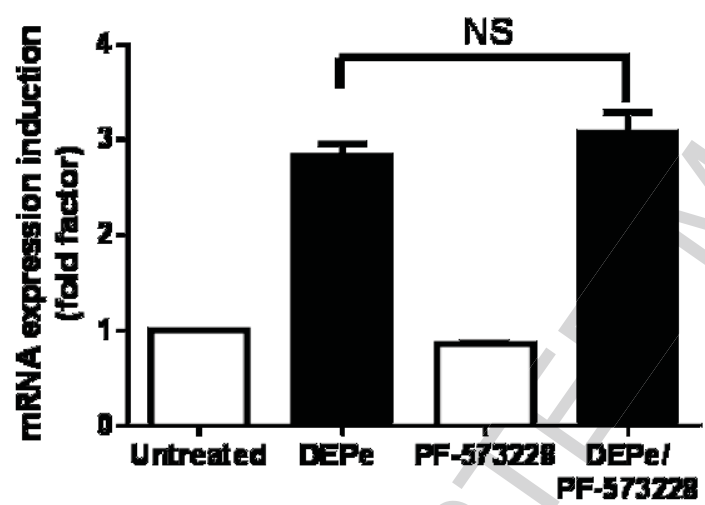

CYP1A1

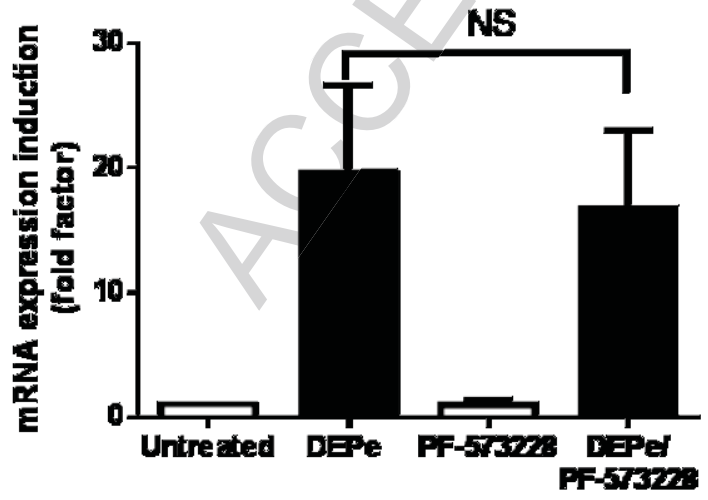

B

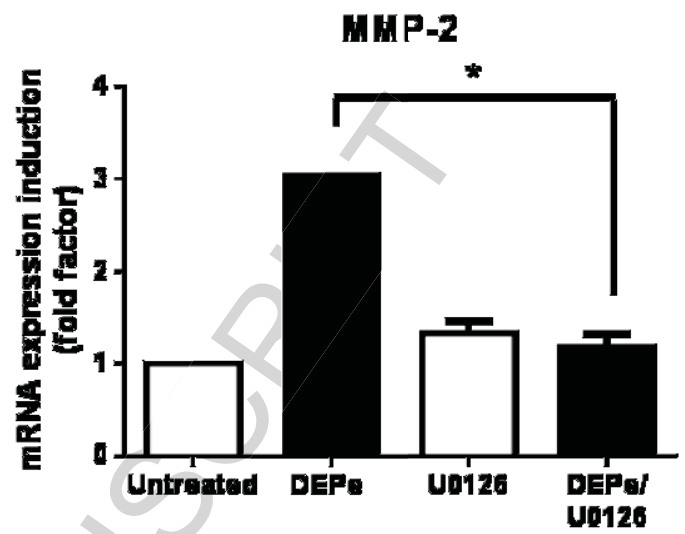

CD98he

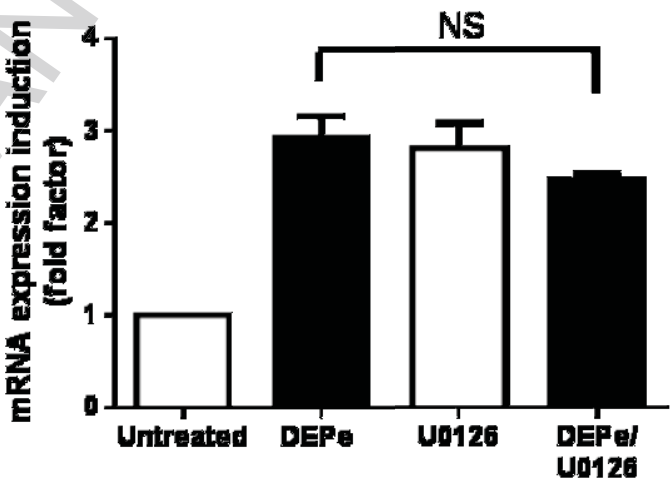

CYP1A1

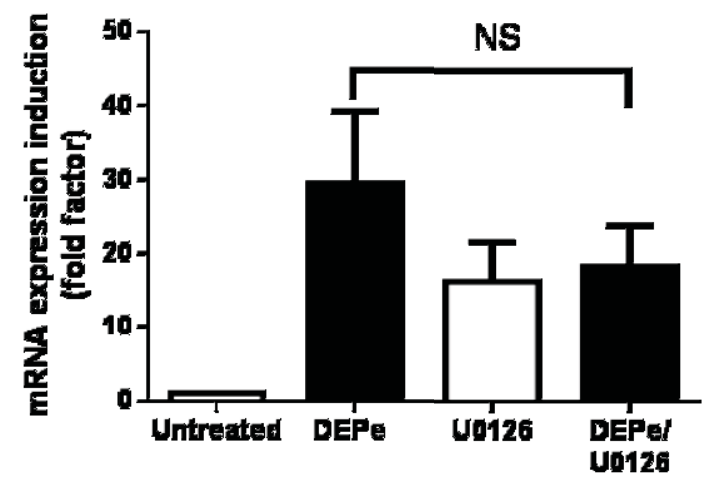

Fig- 9 


\section{Highlights}

- The amino acid transporter LAT1/CD98hc is up-regulated in DEPe-treated lung cells

- The aryl hydrocarbon receptor is involved in DEPe-triggered induction of LAT1/CD98hc

- DEPe enhances LAT1-mediated accumulation of leucine in lung cells

- DEPe increases MMP-2 expression and activity in a CD98hc/FAK/ERK-dependent manner 